University of St. Thomas, Minnesota

UST Research Online

Finance Faculty Publications

Finance

4-2015

Network centrality and mergers

Mufaddal Baxamusa

University of St. Thomas, Minnesota, mufaddalb@stthomas.edu

Follow this and additional works at: https://ir.stthomas.edu/ocbfincpub

Part of the Finance and Financial Management Commons

This Article is brought to you for free and open access by the Finance at UST Research Online. It has been accepted for inclusion in Finance Faculty Publications by an authorized administrator of UST Research Online. For more information, please contact asle4660@stthomas.edu. 


\section{Network centrality and mergers}

\section{Mufaddal Baxamusa, Saima Javaid \& Khadija Harery}

Review of Quantitative Finance and Accounting

ISSN 0924-865X

Volume 44

Number 3

Rev Quant Finan Acc (2015) 44:393-423

DOI 10.1007/s11156-013-0411-7
ISSN 0924-865X

Review of Quantitative Finance and Accounting

$E D / T O R$ :

Cheng-few Lee

ASSOCIATE EDITORS:

Stephen Baginski Robert McDonald

$\begin{array}{ll}\text { Richard T. Baillie } & \text { Siva Nathan } \\ \text { Randolph P. Beatty } & \text { James Ohlso }\end{array}$

Ivan Brick Stephen H. Penma

Stephen Brow

Charles Q. Cao

Thomas J. Ch

Carl R. Chen

Wayne E. Ferson

Jack Clark Francis

Lawrence R. Glosten

Ravi Jaggannathan

Rikki Jaggi

Kose John

Richard E. Kihlstrom

E. Han Kim

Kenneth Lawrence

Andrew W. Lo

Timothy J. Loughran

Joshua Ronen

Ehud Ronn

Robert A. Schwartz

Louis O. Scott

LemmaW. Senbe

Javid B. Smith

David B. Smith

Siew Hong Teoh
Jacob K. Thomas

Sheridan Titman

Charles A. Trzcink

Robert E. Verrecchia

John K.C. Wei

Chunchi Wu

Teri LombardiYohn

iㅡㄹ Springer VOLUME 44, NUMBER 3 APRIL, 2015 
Your article is protected by copyright and all rights are held exclusively by Springer Science +Business Media New York. This e-offprint is for personal use only and shall not be selfarchived in electronic repositories. If you wish to self-archive your article, please use the accepted manuscript version for posting on your own website. You may further deposit the accepted manuscript version in any repository, provided it is only made publicly available 12 months after official publication or later and provided acknowledgement is given to the original source of publication and a link is inserted to the published article on Springer's website. The link must be accompanied by the following text: "The final publication is available at link.springer.com". 


\title{
Network centrality and mergers
}

\author{
Mufaddal Baxamusa $\cdot$ Saima Javaid $\cdot$ Khadija Harery
}

Published online: 14 November 2013

(C) Springer Science+Business Media New York 2013

\begin{abstract}
We hypothesize that the more central a firm in the customer-supplier network the lower is its returns from an acquisition. We find that the acquirers' announcement day abnormal returns decline if the acquirer is more central in the network. Additionally, the target's premiums decline if the target is more central in the network. Lastly, we also find that conditioned on the acquirer's centrality, the acquirer's announcement day abnormal returns increase if more information is available about the target. The centrality of the firm represents information availability of the firm. Thus, information availability may lead to a decline in acquisition returns.
\end{abstract}

Keywords Mergers $\cdot$ Acquisitions $\cdot$ Network $\cdot$ Centrality $\cdot$ Returns

JEL Classification $\quad \mathrm{G} 34 \cdot \mathrm{G} 30$

\section{Introduction}

The seminal work of Grossman and Hart (1980) shows that in mergers and acquisition, the target should obtain a premium which should make the acquirer indifferent to undertaking an acquisition. In other words the acquirer should not generate a profit or loss through an acquisition. The subsequent literature has focused on exploring the conditions under which the acquirer generates a profit or loss. The reasons for the acquirer's returns range from

\footnotetext{
M. Baxamusa ( $\bowtie)$

University of St Thomas, MCH 316, 2115 Summit Avenue, Saint Paul, MN 55436, USA

e-mail: baxa0428@stthomas.edu

S. Javaid $\cdot$ K. Harery

King Abdulaziz University, PO Box 80200, Jeddah 21589, Saudi Arabia

e-mail: harery3000@yahoo.com

K. Harery

e-mail: dr.saimajavaid@gmail.com
} 
managerial agency (e.g. empire buildings; see Jensen 1986) to behavioral reasons (e.g. managerial hubris; Roll 1986). In this paper we put forward an explanation that is not based on agency, hubris or synergy.

We propose that informational availability leads to a higher return in an acquisition. Information about the other party can be employed in merger related negotiations and used to extract the maximum benefit. For example, if the target knows about the strategic reasons underlying the acquirer's preference for the target. Then the target can use that information to extract a higher premium.

The challenge here is to find an empirical proxy for the information availability of the parties undertaking an acquisition. For example, using information asymmetry measures like analyst coverage only allows us to partially study the informational opaqueness of publicly available information. However, there is information that is private. This information content is large and has a significant impact on merger outcomes. The literature finds that the director's social networks significantly impacts merger outcomes (Schonlau and Singh 2009).

We study the customer-supplier networks. The rational being that customers and suppliers have private information about the business of the firm that is valuable. Our primary independent variable is the central position of the party in the supplier-customer network. Information flows from one customer (or supplier) to another in the network (e.g. we talk to you, you talk to your friend, etc.) and so the different measures of centrality like degree and closeness are better proxies for the information availability of the central firm.

We argue that if the firm is more central in the network, then more information about it is known giving the other party advantage in negotiations. Our hypothesis is that the more central the acquirer; lower is the announcement day abnormal returns. Similarly, the more central the target; the larger is the informational disadvantage the lower is the premium. We also investigate a third hypothesis. This hypothesis deals with the information availability of the acquirer and the target. We hypothesize that conditioned on the central position of the acquirer in the network, the returns to the acquirer increases if more information is available about the target.

The use of industry level supplier-customer relationships to proxy for firm level relationships has a long history in the corporate finance literature (Shahrur 2005; Fan and Goel 2006). As in the literature we use the industry level Input-Output benchmark tables from the Bureau of Economic Analysis. We then calculate the central position of the industry in the customer-supplier networks. We find that the announcement day abnormal returns for the acquirer are lower if the firm is more central. We also find that the more central targets receive a lower premium. Consistent with our hypothesis we find that the acquirer's returns increase if more information is available about the target. These results are subject to a number of robustness tests. We use different return variables. We also use an array of centrality measures from weighted to un-weighted network centrality. We find that our results are robust to use of different sets of controls.

In terms of literature, there is a strand that links merger outcomes to different sources of bargaining power like direct product market relations as in A'hern (2012). This paper contributes to the literature by empirically investigating the impact of information on merger outcomes. This is important because it shows the channel through which private information flows can affect bargaining in mergers. This concept of private information affecting merger outcomes has theoretical support (Khanna 1997); however the empirical literature has struggled to convincingly show the results because of weak proxies. This research mitigates this weakness by using centrality measures to proxy for information availability. 
The rest of this paper is as follows. Section 2 reviews the literature and states the hypothesis. Section 3 describes the data and constructs the variables. Section 4 presents the results. We conclude in Sect. 5 .

\section{Literature review and hypothesis development}

The arguments draw on network concepts that emerged in sociology during the 1970s; most notably Granovetter (1973) on the strength of weak ties, Freeman (1979) on degree, closeness and betweenness centrality, Burt (1980) on the structural autonomy created by complex networks. A comprehensive review by Burt (2005) finds evidence that the social capital of structural holes and the contradiction between network closure and structural holes can be resolved in a more general network of social capital. Krakhard and Brass (1994) outline how network analysis can explain six different areas, viz., turnover, attitude, power, motivation, leadership and job design. Theoretically, actors in central network positions are more connected and so more information about them is known. Similarly, information about other non-central actors might be less known as they have fewer connections in the network. Actors who are able to control relevant resources acquire power. Thus, two measures of centrality, closeness (representing access) and betweenness (representing control) corresponds to resource dependence and the degree centrality measures the size of one's ego network (Brass 1984; Krakhard and Brass 1994).

In this section we consider the role of bargaining in a merger. Managers who are better informed about their counter-party's valuation and sources of synergy should be better positioned to negotiate a more profitable deal for their owners.

\subsection{Bargaining in mergers}

A typical merger process proceeds as follows. The acquirer (target) chooses a target (acquirer) with which it wants to pursue merger discussions. After that negotiations begin. At this point the acquirer may choose to perform due diligence of the books of the target to estimate if some of its assumptions about the target are correct. The next step is for the acquirer and the target's management to meet and discuss the terms of the merger. This is now a bargaining game in which the acquirer and the target's management try to extract the maximum rents for their owners. When the managers come to an agreement they announce it to the public. If no information about the merger has leaked, then the stock price reaction to the announcement reflects the probability that the acquisition will complete and the expected benefits to the owners.

\subsection{Information and bargaining}

The acquirer would like to pay less for the acquisition while the target would like to get as high a premium as possible (see Lee and Lim 2006). This division of the synergy, resulting from the merger, happens in a series of negotiations. In a negotiation the importance of information cannot be understated. If the acquirer has an accurate understanding of the valuation of the target, it can price it correctly and pay accordingly. The target may not be able to extract a larger premium as the information asymmetry between the target and the acquirer is small. Similarly, if the target has information about the acquirer's valuation of the synergy, the target will demand a large fraction of the synergy (if not all of it) for their owners. 
In a related study, Etheridge (2010) investigates whether board networks, quantified by measures of centrality and closeness, can affect bargaining power around mergers and acquisitions. His study finds that the board centrality is related to bargaining power; that is, when the bidding company is substantially more central than the target both target board approval and bid completion are more likely. In our study we consider the centrality of the firm and not the centrality of the individual board members.

\subsection{Relevant models for information asymmetry}

These models in general build on the seminal work of Myers and Majluf (1984) and show that information asymmetry between the market and the managers' leads to the market assuming that the managers are trying to take advantage of the markets. Summarizing the vast stream of literature that documents these models is not possible because of space constraint. Thus, we focus on the models that are the most relevant for this research.

One class of models (Miller 1977; Hong et al. 2006; Baxamusa 2012) predict that the diversity of opinion about the future cash flows of the firm lead to decrease in demand for the firm's stocks. The implication for the acquirer is as follows. If an acquisition increases the uncertainty about the future prospects of the acquirer, then the decrease in demand of these stocks because of diversity of opinion will lead to a relative decline in announcement day returns.

Officer et al. (2009) suggests that bidder returns around acquisition announcements are driven by information asymmetry. Their result shows that using stock as a method of payment is beneficial to an acquirer because it is the optimal contract when the target is difficult to value. Further, their study emphasizes that under conditions that suggest that market participants are themselves likely to face uncertainty about the prospective value of the target to the acquirer, i.e. when the privately held firm's financials are not known at the time of the acquisition announcement.

Similarly, Erickson et al. (2011) investigate whether the change in the acquirer's information uncertainty contributes to acquirer wealth losses. Information uncertainty affects the discount rate (the cost of capital), which in turn influences stock price. Their results indicate that acquisitions lead to increases in information uncertainty, as proxied by analysts' earnings forecast dispersion, and also find that the change in information uncertainty is negatively related to acquirer long-term stock performance, after controlling for the acquirer's fundamentals.

A second class of models developed in Travlos (1987) shows that the announcement of the acquisition signals to the market that the acquirer is overvalued. Therefore, the acquirer announcement returns for the firms with more information asymmetry will be more negative. A third class of models by P'astor and Veronesi (2006) show that uncertainty about the firm increases its value. This is especially true when there is uncertainty about the growth prospects of the firm. If this argument is extended then it suggests that the uncertainty about the target increase its value and the premium it can command. Thus, target about which there is less information available and so more uncertain is likely to have a larger premium.

\subsection{Hypotheses}

The above arguments suggest that if the acquirer's valuation and sources of synergy is known then it leads to a decline in the acquirer's bargaining power. This in turn reduces the 
fraction of the synergy the acquirer's managers are able to get in a merger. Thus, the stock market's reaction to the announcement of the acquisition should be negative.

If an actor is more central then as a consequence it may increases the information's quality, relevance, and timeliness about the actor. The reason is that the central actors have interaction with more actors increasing the information flow about the central actor. Similarly, if the firm's industry has many customer and supplier industries then the information about the firm's industry will be more widely known. We can argue that if the firm belongs to a central industry then the information about this firm is also more likely to be known than firms which belong to less central industries. Thus, the hypothesis follows:

$\mathbf{H}_{1}$ : The announcement day abnormal returns to the acquirer which is more central in a network is relatively more negative.

Now, let us apply the same set of arguments to the target. If more information is known about the target, then the bargaining power of the target gets reduced resulting in the acquirer obtaining a larger fraction of the synergy. Thus, the more information is known about the target the higher is the announcement day stock returns for the acquirer.

Measuring the amount of information of non-publicly traded targets available to the acquirer is difficult. So, the literature typically uses the size of the target as a proxy for information. The reason is that if the firm is large it has more stakeholders and more popular press articles leading to an increase in information of the firm. Another proxy is whether the target is publicly traded or is privately held. If the target is privately held, then there is less information available as these firms do not need to file annual reports to SEC or disclose any information to the public.

An implication of the above arguments is that if more information is known about the target and if the acquirer is more central, then the acquirer is more likely to obtain the private information. Thus, the hypothesis follows:

$\mathbf{H}_{2}$ : The announcement day abnormal returns to the acquirer which is more central in a network increases if the target is public and is larger in size, conditioned on the negative returns based on the acquirers central position in the network.

An alternate way to measure the information availability of the target is to consider the industry's network centrality. As before, we argue that if the target's industry is more central, then more information about the target is available to the acquirer. The above arguments suggests that a smaller fraction of the synergy being obtained by the more central target.

$\mathbf{H}_{3}$ : The premium to a target which is less central in a network is higher than the premium to a target that is more central in a network, all else equal.

A'hern (2012) hypothesizes that the division in gains in mergers depend on the customer-supplier relations in the product market. Although A'hern (2012) and this paper contribute to the same strand of research which explains merger returns based on bargaining power (Boone and Mulherin 2006; Povel and Singh 2006); however there are a number of important differences between both these papers. The theoretical underpinnings for A'hern come from transaction cost economics. A'hern argues that a customer could be dependent on a supplier because the supplier's inputs are crucial to the customer. A'hern links this dependence to bargaining power and states that firms that are more productmarket dependent on the other have a weaker bargaining position and so gain a smaller fraction of the synergy. 
Our hypotheses come from information economics and we argue that information per se and not product market dependencies gives bargaining power to the firms involved in a merger. For instance, if a target knows that it is valuable to the acquirer for a certain strategic reason (e.g. entry into a new industry, customer base, production knowledge, patents, etc.), then the target can use that information to extract a larger premium from the acquirer. Note that none of the above examples necessitates a direct or potential customersupplier relationship as in A'hern (2012).

\section{Data and variable construction}

\subsection{Centrality measures}

A'hern (2012) uses the ratio of one industry's inputs to another industry's outputs to measure firm level customer-supplier dependence. In this paper the focus is not on trading relationships but on information flow. For instance, two firms may not be in industries that have direct trading relationship, but may still have information about each other. Thus, the measure used by A'hern (2012) is not appropriate in this research. Another issue with interpreting the product market based A'hern measure as a proxy for information flow is that two industries might have a weak customer supplier relationship but might still have a significant amount of information about each other.

To overcome the challenge of having a proxy for the measure of information availability of a firm we proceed as follows. We assume that a channel of information flow is between the customers and suppliers. Thus, one method is to trace the path of information flow. In terms of graph theory, all the customer-supplier relationships are part of a large network with each industry being a node. Some nodes in this network are more important than others. Graph theory has put forward some network statistics (e.g. degree, closeness, betweenness, etc.) to reflect the importance of these nodes in relation to other nodes which are directly or indirectly connected through a number of intermediate industries. This approach has the advantage that unlike A'hern (2012) two firms need not belong to industries that have direct trading relationships. We only require that the two firms be part of the broad inter-industry network. We are fortunate that all the industries are part of this network and so are able to formulate our empirical strategy for testing our hypotheses about information availability of a firm and the returns from mergers.

The building block of these centrality measures is the Benchmark Input-Output Use Table provided by the Bureau of Economic Analysis. ${ }^{1}$ The Use Table is a matrix containing the value of commodity flows between each pair of roughly 500 private-sector, intermediate six-digit IO industries (see Lawson 1997) for detailed description of the dataset). The benchmark tables are reported every 5 years $(1982,1987,1992,1997,2002)$. The latest table available is that of 2002. The 2007 tables have not yet been published. The table reports for each pair of industries, $i$ and $j$, the value of i's output required to produce industry j's total output $\left(\mathrm{a}_{\mathrm{ij}}\right)$. Bureau of Economic Analysis publishes these benchmark tables every 5 years and regularly modifies the industry classifications. Hence, a concordance is hand constructed by going through each industry classification and then mapping previous industry classifications to the current industry classifications. The next step is to construct the standard centrality measure. The most commonly used centrality measure is degree. Degree counts the number of ties the industry has with other industries. The rest of

\footnotetext{
${ }^{1}$ The data can be freely downloaded from: http://www.bea.gov/industry/io_benchmark.htm.
} 
the centrality measures are defined in the "Appendix". In general, the weighted centrality measures are more informative as they use all available information.

Table 1 panel A reports the median and the standard deviation of the of the centrality measures. It seems that there is no time pattern for the changes in the centrality measures that can be generalized to all (or most) of the centrality measures. This can be seen by degree first decreasing and then increasing; while the weighted eigenvector centrality measure increases over time. In unreported tables the statistical significance of these changes were found to be insignificant. It seems that these centrality measures are stable in the sense that there is no time pattern. The implication here is that the regression results reported later in the paper are not likely to be driven by the time-trend in the centrality measures.

Table 1 panel B reports the correlation between the different centrality measures. It appears that degree and eigenvector are $95 \%$ correlated. After that degree is $67 \%$ correlated with closeness. Weighted eigenvector weighted is $90 \%$ correlated with weighted degree, and $80 \%$ correlated with out-degree and in-degree. As expected most of these measures are highly correlated suggesting that most of these centrality measures capture some variations in the industry's centrality.

\subsection{Mergers and acquisitions data and centrality}

The source of the mergers and acquisitions data is Security Data Corporation's (SDC) dataset. Here we apply the standard filters from the literature (see Moeller et al. 2004; Baxamusa and Georgieva 2013):

- The announcement date is between 1980 and 2010;

- The acquirer controls less than $50 \%$ of the shares of the target at the announcement date and obtains $100 \%$ of the target shares;

- The deal value exceeds or equals $\$ 1$ million;

- The transaction size is more than $1 \%$ of the value of the acquirer (and)

- The deal completion time is less than 1,000 days.

The observations in the sample without SIC codes were dropped. Additionally, observations with SIC codes that did not match SIC codes from in http://www.osha.gov/pls/imis/ sicsearch.html were dropped (for example some observations had SIC code 2000; however there is no such SIC code). This cleaning of data is important as the firm's industries are used to create a network of industries and the position of the industries in these networks is taken as a proxy for the firm's centrality. Additionally, the publicly traded firms should have data in Compustat. The sample consists of 15,387 public traded acquirers and 2,234 acquisitions with both the acquirer and the target being publicly traded.

Table 2 panel A reports the centrality measures for the acquirer; while Table 2 panel B reports the centrality measure for the target firms. In both panels $\mathrm{A}$ and $\mathrm{B}$ there is no obvious time trend. This is consistent with the findings of Table 1 Panel A. In terms of comparing panels A and B of Table 2, it seems that in columns (1), (2), (4) and (5) the value of degree of the acquirer is larger than that of the target. However, for other measures of centrality no clear time pattern exists for the relationship between the centrality of the target and the centrality of the acquirer.

Table 3 panel A and panel B report the summary statistics of some of the key variables. The first few rows report the key summary statistics of centrality measures. Unlike Table 2 these measures are pooled across the years and do not show the time series patterns. The degree centrality measure for the acquirer as reported in Table 3 Panel A is 60.49 in 


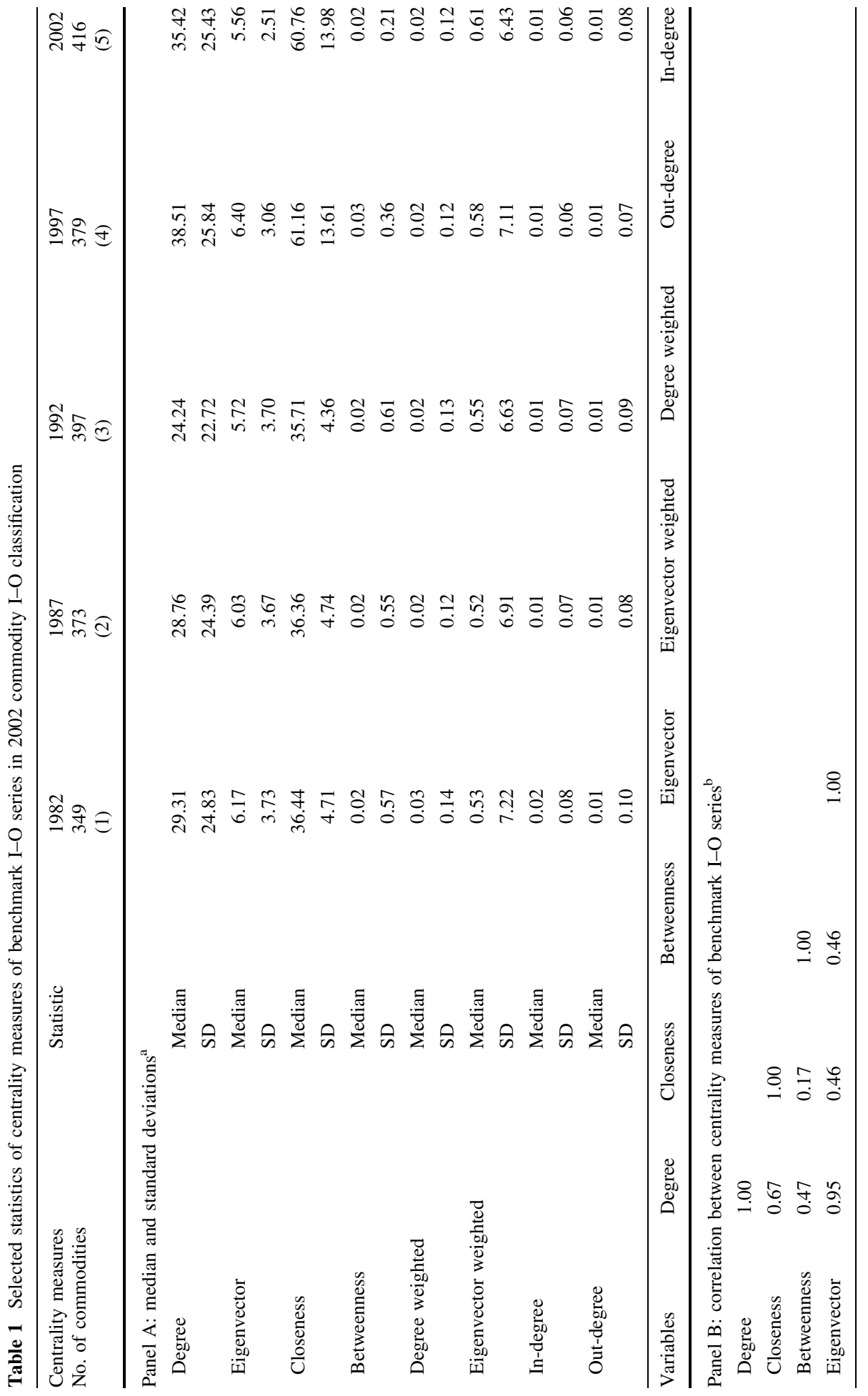




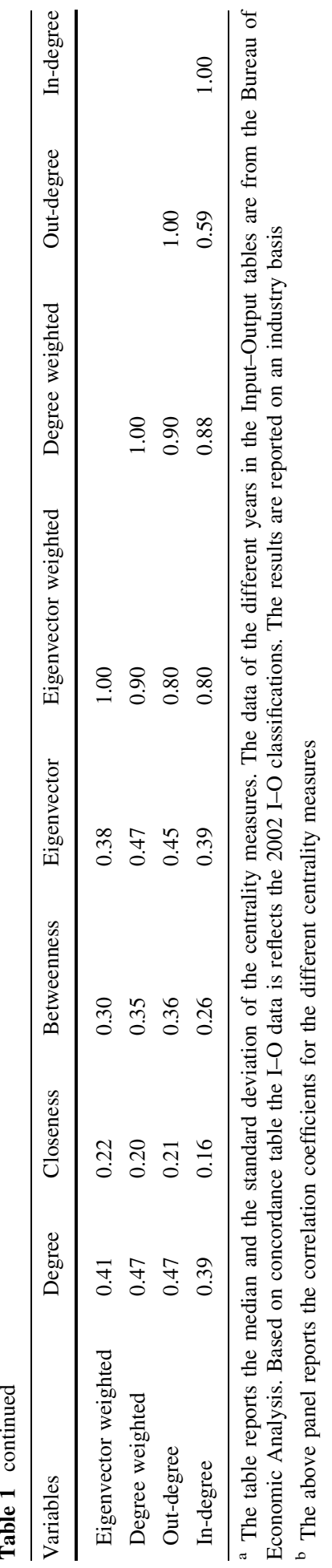


Table 2 Descriptive statistics of centrality measures

\begin{tabular}{|c|c|c|c|c|c|c|}
\hline $\begin{array}{l}\text { Centrality measures } \\
\text { No. of acquirers }\end{array}$ & Statistic & $\begin{array}{l}80-84 \\
1,105 \\
(1)\end{array}$ & $\begin{array}{l}85-89 \\
1,230 \\
(2)\end{array}$ & $\begin{array}{l}90-94 \\
2,343 \\
(3)\end{array}$ & $\begin{array}{l}95-99 \\
5,317 \\
(4)\end{array}$ & $\begin{array}{l}00-10 \\
5,392 \\
(5)\end{array}$ \\
\hline \multicolumn{7}{|l|}{ Panel A: acquirers ${ }^{\mathrm{a}}$} \\
\hline \multirow[t]{2}{*}{ Degree } & Median & 72.13 & 43.01 & 31.57 & 54.89 & 59.04 \\
\hline & SD & 29.56 & 30.76 & 30.93 & 29.07 & 29.44 \\
\hline \multirow[t]{2}{*}{ Eigenvector } & Median & 11.65 & 8.02 & 7.14 & 9.59 & 7.92 \\
\hline & SD & 4.12 & 4.41 & 4.64 & 3.23 & 2.80 \\
\hline \multirow[t]{2}{*}{ Closeness } & Median & 44.05 & 38.55 & 36.74 & 76.15 & 70.94 \\
\hline & SD & 5.60 & 6.16 & 5.91 & 15.77 & 17.11 \\
\hline \multirow[t]{2}{*}{ Betweenness } & Median & 0.48 & 0.14 & 0.14 & 0.22 & 0.13 \\
\hline & SD & 0.41 & 0.39 & 0.46 & 1.04 & 0.28 \\
\hline \multirow[t]{2}{*}{ Degree weighted } & Median & 0.15 & 0.07 & 0.08 & 0.06 & 0.10 \\
\hline & SD & 0.29 & 0.25 & 0.29 & 0.31 & 0.24 \\
\hline \multirow[t]{2}{*}{ Eigenvector weighted } & Median & 3.23 & 1.92 & 3.68 & 2.26 & 4.71 \\
\hline & SD & 12.77 & 15.23 & 14.78 & 17.05 & 14.03 \\
\hline \multirow[t]{2}{*}{ In-degree } & Median & 0.06 & 0.04 & 0.05 & 0.03 & 0.06 \\
\hline & SD & 0.18 & 0.17 & 0.16 & 0.16 & 0.14 \\
\hline \multirow[t]{2}{*}{ Out-degree } & Median & 0.05 & 0.03 & 0.04 & 0.02 & 0.03 \\
\hline & SD & 0.20 & 0.16 & 0.20 & 0.20 & 0.16 \\
\hline $\begin{array}{l}\text { Centrality measures } \\
\text { No. of targets }\end{array}$ & Statistic & $\begin{array}{l}80-84 \\
149 \\
(1)\end{array}$ & $\begin{array}{l}85-89 \\
237 \\
(2)\end{array}$ & $\begin{array}{l}90-94 \\
265 \\
(3)\end{array}$ & $\begin{array}{l}\text { 95-99 } \\
811 \\
(4)\end{array}$ & $\begin{array}{l}00-10 \\
772 \\
(5)\end{array}$ \\
\hline \multicolumn{7}{|l|}{ Panel B: targets ${ }^{\mathrm{b}}$} \\
\hline \multirow[t]{2}{*}{ Degree } & Median & 44.54 & 38.98 & 47.73 & 42.82 & 63.86 \\
\hline & SD & 27.94 & 30.71 & 31.73 & 29.13 & 30.62 \\
\hline \multirow[t]{2}{*}{ Eigenvector } & Median & 7.31 & 7.43 & 9.22 & 9.25 & 8.20 \\
\hline & SD & 3.95 & 4.39 & 4.61 & 3.30 & 2.92 \\
\hline \multirow[t]{2}{*}{ Closeness } & Median & 37.46 & 37.39 & 39.05 & 75.26 & 73.45 \\
\hline & SD & 5.39 & 6.20 & 6.01 & 15.72 & 17.67 \\
\hline \multirow[t]{2}{*}{ Betweenness } & Median & 0.06 & 0.08 & 0.34 & 0.22 & 0.18 \\
\hline & SD & 0.61 & 0.38 & 0.50 & 0.97 & 0.28 \\
\hline \multirow[t]{2}{*}{ Degree weighted } & Median & 0.09 & 0.06 & 0.21 & 0.05 & 0.11 \\
\hline & SD & 0.35 & 0.25 & 0.29 & 0.25 & 0.23 \\
\hline \multirow[t]{2}{*}{ Eigenvector weighted } & Median & 1.29 & 1.73 & 9.74 & 2.04 & 4.82 \\
\hline & SD & 16.40 & 15.37 & 13.45 & 14.94 & 13.44 \\
\hline \multirow[t]{2}{*}{ In-degree } & Median & 0.05 & 0.03 & 0.10 & 0.03 & 0.06 \\
\hline & SD & 0.22 & 0.17 & 0.16 & 0.14 & 0.12 \\
\hline
\end{tabular}


Table 2 continued

\begin{tabular}{lllllll}
\hline $\begin{array}{l}\text { Centrality measures } \\
\text { No. of targets }\end{array}$ & Statistic & $\begin{array}{l}80-84 \\
149 \\
(1)\end{array}$ & $\begin{array}{l}85-89 \\
237 \\
(2)\end{array}$ & $\begin{array}{l}90-94 \\
265 \\
(3)\end{array}$ & $\begin{array}{l}95-99 \\
811 \\
(4)\end{array}$ & $\begin{array}{l}00-10 \\
772 \\
(5)\end{array}$ \\
\hline Out-degree & Median & 0.03 & 0.02 & 0.09 & 0.01 & 0.05 \\
& SD & 0.24 & 0.15 & 0.20 & 0.16 & 0.17 \\
\hline
\end{tabular}

a The table reports the median and the standard deviation of the centrality measures. The reported data is for the industry's of the acquirer firms. The data of the different years in the Input-Output tables are from the Bureau of Economic Analysis. Based on concordance table the I-O data is reflects the 2002 I-O classifications. The results are reported on an industry basis

b The table reports the median and the standard deviation of the centrality measures. The reported data is for the industry's of the target firms. The data of the different years in the Input-Output tables are from the Bureau of Economic Analysis. Based on concordance table the I-O data is reflects the $2002 \mathrm{I}-\mathrm{O}$ classifications. The results are reported on an industry basis

column (1) while the centrality measure for the target variable in panel B is 58.69. The difference between these two means is not statistically significant. This lack of statistical significance between the means of the acquirer and the target variables is true for all the centrality measures and is consistent with the implications of Table 2.

\subsection{Other variables}

Table 3 reports the summary statistics of other variables used in the analysis. Panel A reports that the announcement day abnormal returns for the acquirer are positive. This is consistent with the findings of Moeller et al. (2004). The acquirers in the sample have a mean Tobin's Q of 2.319 and an average leverage ratio of about $19 \%$. For the public acquirer the about $18.9 \%$ of the deals are fully financed with the acquirers stock, and $63 \%$ of the acquirers tend to be in high tech industries.

Table 3 panel b reports that the average target has a Tobin's Q of 2.06 and has an average leverage of about $16.7 \%$. The $38.26 \%$ of the acquisitions between publicly traded acquires and publicly traded targets are fully financed with the acquirer's stock; while $24.38 \%$ of such transactions are fully financed by cash. The target receives a $22.29 \%$ mark-up above its announcement day stock price and the markup including the run-up of the stock is $33.57 \%$.

\section{Results}

\subsection{Empirical model}

The hypothesis are empirically tested using the following model:

$$
\text { Returns }_{i}=\alpha+\beta_{1} \text { Weighted Central }_{i}+\beta_{2} X_{i}+\varepsilon_{i} \ldots
$$

We follow Masulis et al. (2007) for the empirical model. This is a good model as it controls for most of the known sources of abnormal returns. The literature documents that the returns to the acquirer comes from three sources. These sources are the firm characteristics, the bid characteristics and industry characteristics. These sources are part of the control 
Table 3 Summary statistics

\begin{tabular}{|c|c|c|c|c|c|}
\hline Variable & $\begin{array}{l}\text { Mean } \\
(1)\end{array}$ & $\begin{array}{l}\text { Median } \\
\text { (2) }\end{array}$ & $\begin{array}{l}\text { Std. Dev. } \\
\text { (3) }\end{array}$ & $\begin{array}{l}\text { Min } \\
(4)\end{array}$ & $\begin{array}{l}\operatorname{Max} \\
(5)\end{array}$ \\
\hline \multicolumn{6}{|l|}{ Panel A: acquirer variables ${ }^{a}$} \\
\hline \multicolumn{6}{|l|}{ Centrality } \\
\hline Degree & 60.4999 & 63.8550 & 31.0443 & 0.2530 & 100.0001 \\
\hline Eigenvector & 8.7306 & 9.4150 & 3.4828 & 0.0220 & 13.9630 \\
\hline Closeness & 68.0155 & 62.5900 & 22.8070 & 25.8690 & 100.0001 \\
\hline Betweenness & 0.3997 & 0.2500 & 0.6082 & 0.0001 & 10.3710 \\
\hline Degree weighted & 0.2690 & 0.1000 & 0.3152 & 0.0001 & 1.3220 \\
\hline Eigenvector weighted & 14.5754 & 4.7100 & 18.2656 & 0.0001 & 81.3010 \\
\hline In-degree & 0.1315 & 0.0580 & 0.1570 & 0.0001 & 0.7750 \\
\hline Out-degree & 0.1694 & 0.0450 & 0.2311 & 0.0001 & 1.0370 \\
\hline \multicolumn{6}{|l|}{ Returns } \\
\hline 3-day abnormal returns & 0.0103 & 0.0034 & 0.0819 & -0.6990 & 1.5186 \\
\hline 5-day abnormal returns & 0.0115 & 0.0039 & 0.0955 & -0.6804 & 1.6448 \\
\hline \multicolumn{6}{|l|}{ Firm characteristics } \\
\hline Tobin's Q & 2.3199 & 1.4625 & 6.4566 & 0.1135 & 548.1840 \\
\hline Cash Flow & 0.0908 & 0.1461 & 3.5119 & -380.3913 & 1.2706 \\
\hline Leverage & 0.1917 & 0.1284 & 0.2243 & 0.0001 & 6.8794 \\
\hline Size & $3,616.2340$ & 290.2230 & $28,170.0200$ & 0.0010 & $129,180.0000$ \\
\hline \multicolumn{6}{|l|}{ Bid characteristics } \\
\hline Deal size & 0.4766 & 0.0855 & 16.2619 & 0.0110 & 1994.9170 \\
\hline All equity & 0.1890 & 0.0001 & 0.3915 & 0.0001 & 1.0000 \\
\hline All cash & 0.2275 & 0.0001 & 0.4192 & 0.0001 & 1.0000 \\
\hline Conglomerate & 0.3395 & 0.0001 & 0.4735 & 0.0001 & 1.0000 \\
\hline High tech & 0.6336 & 1.000 & 0.4819 & 0.000 & 1.000 \\
\hline Ln(Transaction value) & 3.7134 & 3.5729 & 1.8015 & 0.2263 & 11.3983 \\
\hline \multicolumn{6}{|l|}{ Industry } \\
\hline Product market competition & 0.1965 & 0.1244 & 0.2206 & 0.0001 & 1.0000 \\
\hline Tobin's Q & 1.5549 & 1.3398 & 2.8558 & 0.4337 & 281.2500 \\
\hline Cash flow & 0.0924 & 0.1028 & 0.2320 & -8.6630 & 1.0023 \\
\hline Leverage & 0.1206 & 0.0637 & 0.1562 & 0.0001 & 8.3941 \\
\hline Size & 683.4105 & 72.0460 & $2,961.4940$ & 0.3120 & $94,175.0400$ \\
\hline \multicolumn{6}{|l|}{ Panel B: target variables ${ }^{\mathrm{b}}$} \\
\hline \multicolumn{6}{|l|}{ Centrality } \\
\hline Degree & 58.6933 & 57.7590 & 31.3610 & 0.0001 & 100.0001 \\
\hline Eigenvector & 8.6661 & 9.4150 & 3.5257 & 0.0001 & 13.9630 \\
\hline Closeness & 67.4223 & 61.7560 & 22.9182 & 26.5950 & 100.0001 \\
\hline Betweenness & 0.3955 & 0.2200 & 0.5907 & 0.0001 & 5.8010 \\
\hline Degree weighted & 0.2361 & 0.1000 & 0.2774 & 0.0001 & 1.3220 \\
\hline Eigenvector weighted & 12.8036 & 4.2130 & 15.8277 & 0.0001 & 81.3010 \\
\hline In-degree & 0.1213 & 0.0510 & 0.1478 & 0.0001 & 0.7750 \\
\hline Out-degree & 0.1444 & 0.0450 & 0.1990 & 0.0001 & 1.0370 \\
\hline \multicolumn{6}{|l|}{ Returns } \\
\hline Premium & 0.0018 & 0.0016 & 0.0011 & 0.0001 & 0.0192 \\
\hline Mark-up & 0.2229 & 0.1826 & 0.3931 & -3.1909 & 3.5836 \\
\hline
\end{tabular}


Table 3 continued

\begin{tabular}{llllll}
\hline Variable & $\begin{array}{l}\text { Mean } \\
(1)\end{array}$ & $\begin{array}{l}\text { Median } \\
(2)\end{array}$ & $\begin{array}{l}\text { Std. Dev. } \\
(3)\end{array}$ & $\begin{array}{l}\text { Min } \\
(4)\end{array}$ & $\begin{array}{l}\text { Max } \\
(5)\end{array}$ \\
\hline $\begin{array}{l}\text { Mark-up plus run-up } \\
\text { Firm characteristics }\end{array}$ & 0.3357 & 0.2997 & 0.5877 & -11.0309 & 4.1518 \\
Tobin's Q & & & & 0.2783 & 38.0510 \\
Cash flow & 2.0611 & 1.3957 & 2.3364 & -1.8241 & 1.2456 \\
Leverage & 0.1460 & 0.1311 & 0.1866 & 0.0001 & 1.2069 \\
Size & 0.1677 & 0.1211 & 0.1701 & 0.1760 & $902,210.0001$ \\
Bid characteristics & 9983.6810 & 1372.8150 & 43351.8500 & & 20.7644 \\
Deal size & & & & 0.0111 & 1.0000 \\
All equity & 0.3564 & 0.1590 & 0.7699 & 0.0001 & 1.0000 \\
All cash & 0.3826 & 0.0001 & 0.4861 & 0.0001 & 1.0000 \\
Conglomerate & 0.2438 & 0.0001 & 0.4295 & 0.0001 & 1.000 \\
High tech & 0.3609 & 0.0001 & 0.4804 & 0.0001 & 1.0000 \\
Industry & 0.6581 & 1.000 & 0.4744 & & 15.2872 \\
Product market competition & 0.1778 & 0.1088 & 0.2132 & 0.0001 & 0.7737 \\
Tobin's Q & 1.4258 & 1.2542 & 1.0101 & 0.2489 & -3.4089 \\
Cash Flow & 0.0730 & 0.0760 & 0.1966 & 0.0001 & 46.8324 \\
Leverage & 0.1234 & 0.0584 & 0.9115 & 0.8470 & $82,195.7000$ \\
Size & 646.8861 & 73.9515 & $3,234.5130$ & & \\
\hline
\end{tabular}

a The total number of observations are 15378. The sample period is 1980-2010. The sample is the overlap between the data from SDC and Compustat. Only, the observations for the acquirer are reported in this panel. Mean is the sample average, the median is the sample's median value, SD is the standard deviation of the sample, Min is the minimum value of the observation in the sample, Max is the maximum value of the observations in the sample. The returns are calculated using the market model. The estimation window starts 30 days before the event and consists of 150 trading days. The event window is 3 days around the announcement day, and 5 days about the announcement date. Tobin's $\mathrm{Q}$ is the ratio of the market value of the firms assets (market capitalization plus total liability) divided by the total assets of the firm. Cash flows is EBITDA/total assets. Leverage is total liability divided by total assets. Size is the total assets of the firm. Deal size is the ratio for the target's total assets to the acquirer's total assets. All Equity and all cash are dummy variables that take the value of one if the acquisition is fully paid with the acquirers stock or is in cash. Conglomerate is a dummy variable that takes the value of one if the acquisition leads to diversification. High tech is a dummy variable that takes the value of one if the target belongs to the technology industries as identified by SDC. Ln(Transaction value) is the log of the transaction value which is supplied by SDC. Product market competition is the Herfidahl index of the industry. The mean industry values are reported for the other industry measures

b The total number of observations are 2,234. The sample period is 1980-2010. The sample is the overlap between the data from SDC and Compustat. Only, the observations for the target are reported in this panel. Mean is the sample average, the median is the sample's median value, SD is the standard deviation of the sample, Min is the minimum value of the observation in the sample, Max is the maximum value of the observations in the sample. Premium is the ratio of the transaction value to the value of the market value of the target. Mark-up is the 1 day change in the target's stock price about the announcement of the acquisition. Markup-plus run-up is the change in the price of the target's stock over a 1 month period before the announcement day in addition to the mark-up. Tobin's Q is the ratio of the market value of the firms assets (market capitalization plus total liability) divided by the total assets of the firm. Cashflows is EBITDA/total assets. Leverage is total liability divided by total assets. Size is the total assets of the firm. Deal size is the ratio for the target's total assets to the acquirer's total assets. All Equity and all cash are dummy variables that take the value of one if the acquisition is fully paid with the acquirers stock or is in cash. Conglomerate is a dummy variable that takes the value of one if the acquisition leads to diversification. High tech is a dummy variable that takes the value of one if the target belongs to the technology industries as identified by SDC. Ln(Transaction value) is the log of the transaction value which is supplied by SDC. Product market competition is the Herfidahl index of the industry. The mean industry values are reported for the other industry measures 
variables in the above model. In the above equation returns refers to the 3-day abnormal announcement day returns for the acquirer. Weighted Central refers to the weighted centrality of the acquirer. $\mathrm{X}$ represents an array of standard controls from the literature. These controls are divided into three categories. The first category deals with firm characteristics. These firm characteristics include growth (Tobin's q), agency cost (cash flow), financial constraint (leverage), and the size of the firm. The second category of controls represents the characteristics of the deal. The deal characteristics that are controlled for are the relative size of the deal, whether the mode of payments is cash or non-cash (Kohers et al. 2007), if the deal is classified as hostile or neutral by SDC, and if the target is a technology firm. The third category of controls represents industry characteristics. The industry characteristics are the industry's median Tobin's Q, cash flows, and leverage. Additionally, Fama and French's 49 industry dummies and year dummies are employed but not reported.

The empirical strategy is different than A'hern (2012). I use the industry's centrality in a network as a proxy for bargaining power (see also Aggarwal and Baxamusa 2013), while A'hern (2012) uses customer-supplier relationships and firm characteristics like Marketto-book and profitability as proxies for bargaining power. The issue with market-to-book is that it represents an array of firm characteristics including stock market investor irrationality. In addition to bargaining power, profitability also reflects the agency cost of free cash flows.

\subsection{Acquirer's abnormal returns and centrality}

In this sub-section we test the first hypothesis which is that the acquirer's abnormal return to the acquirer has a negative relationship to the acquirers' centrality in the network. We employ Eq. (1) to test the hypothesis. In Table 4 Eq. (1) is estimated but without any other controls. Table 4 Panel (A) reports a negative relationship between 3-day Abnormal returns and the measures of acquirer's centrality in each of the four columns. These estimates are statistically significant at the $1 \%$ confidence level.

Panel (B) reports the relationship between 3-day abnormal returns and weighted centrality measures. Closeness and betweenness cannot be calculated using the weights, however directional measures like in-degree and out-degree can be calculated. Panel (B) reports that the variables of interest in each of the four columns have a negative relationship. This suggests that even with weighted centrality measures the acquirer returns are negative. These results are consistent with the findings of Panel (A).

Panel (C) investigates whether the results reported in Table 4 panel (A) are robust to using direct customer-supplier relationship as an additional control. To test it we add the independent variable Acquirer Input/Target Output from A'hern (2012) to the centrality measures used in panel (A). Panel (C) reports that the centrality measure in each of the four columns retains its statistical significance while the customer-supplier relationship measured by Acquirer Input/Target Output is generally not statistically significant. The implication here is that the relationship reported in panel (A) is robust to direct customersupplier relationship and so the relationship reported in this paper is different from those in A'hern (2012).

The estimates reported in Table 4 do not use any controls, so one of the criticism can be that these results are driven by other known causes. In Table 5 we mitigate this criticism by including other controls from the literature. In terms of controls, the first set is firm characteristics. The literature documents that the relationship between the acquirer's abnormal announcement day returns and the acquirer's Tobin's Q is negative. Lang et al. 
Table 4 Regression of abnormal returns to acquirer with no controls

\begin{tabular}{|c|c|c|c|c|}
\hline 3-day abnormal returns & (1) & (2) & (3) & (4) \\
\hline \multicolumn{5}{|c|}{ Panel A: symmetric non-weighted centrality measures as independent variables ${ }^{\mathrm{a}}$} \\
\hline \multirow[t]{2}{*}{ Degree } & -0.000 & & & \\
\hline & $2.78 * *$ & & & \\
\hline \multirow[t]{2}{*}{ Eigenvector } & & -0.0006 & & \\
\hline & & $3.10 * *$ & & \\
\hline \multirow[t]{2}{*}{ Closeness } & & & -0.0001 & \\
\hline & & & $3.60 * *$ & \\
\hline \multirow[t]{2}{*}{ Betweenness } & & & & -0.0030 \\
\hline & & & & $2.68 * *$ \\
\hline \multirow[t]{2}{*}{ Constant } & 0.0135 & 0.0159 & 0.0171 & 0.0119 \\
\hline & $9.69 * *$ & $8.41^{* *}$ & $8.77 * *$ & $14.19 * *$ \\
\hline Observations & 15,378 & 15,378 & 15,378 & 15,378 \\
\hline$R^{2}$ & 0.001 & 0.001 & 0.001 & 0.001 \\
\hline
\end{tabular}

Panel B: weighted centrality measures as independent variables ${ }^{\mathrm{b}}$ Symmetric centrality

Degree weighted

Eigenvector weighted

$3.97 * *$

Directed centrality

In-degree

$2.11 *$

Out-degree

$5.16^{* * *}$

$13.44^{* *}$

$13.75^{\text {** }}$

$12.51^{* *}$

$14.61 * *$

Observations

15,378

15,378

0.001

0.001

15,378

15,378

$R^{2}$

0.000

0.001

Panel C: Robustness to direct customer-supplier relationship ${ }^{c}$
Degree
$-0.0001$
$2.24^{*}$

Eigenvector

$2.09 *$

Closeness

$-0.0001$

$2.76^{* *}$

Betweenness

$-0.0015$

$2.88 * *$

Acquirer input/target output

-0.0726
1.23
0.0156
$9.66^{* *}$

$-0.0241$

$-0.1185$

$-0.1326$

0.94

$2.29 *$

1.30

Constant

0.0128

0.0160

0.0128

$9.66^{* *}$

$8.77^{* *}$ 
Table 4 continued

\begin{tabular}{lllll}
\hline 3-day abnormal returns & $(1)$ & $(2)$ & $(3)$ & $(4)$ \\
\hline Observations & 15,378 & 15,378 & 15,378 & 15,378 \\
$R^{2}$ & 0.001 & 0.001 & 0.001 & 0.001 \\
\hline
\end{tabular}

${ }^{a}$ This table reports the relationship between acquirers abnormal returns and the acquirers non-weighted centrality measures. OLS regression methodology is used with clustered standard errors. The variables are defined in previous tables. The standard errors are clustered at the industry level (Fama-French 49 industries). $* * *$ represents statistical significance at the 1 and $5 \%$ level respectively

b This table reports the relationship between acquirers abnormal returns and the acquirers weighted centrality measures. OLS regression methodology is used with clustered standard errors. The variables are defined in previous tables. The standard errors are clustered at the industry level (Fama-French 49 industries). **, * represents statistical significance at the 1 and $5 \%$ level respectively

c This table reports the relationship between acquirers abnormal returns and the acquirers non-weighted centrality measures. OLS regression methodology is used with clustered standard errors. The variables are defined in previous tables. The standard errors are clustered at the industry level (Fama-French 49 industries). $* *, *$ represents statistical significance at the 1 and $5 \%$ level respectively

(1989) suggest that the reason is that acquirers with poorer growth prospects (low Tobin's Q firms) are acquiring targets with better growth prospects. Jensen (1986) finds that firms with higher amount of free cash flows have more shareholder-manager agency conflicts, manifesting in value destroying acquisitions. Thus, we should expect a negative relationship between acquirer announcement day abnormal returns and acquirer cash flows. Leverage is an important governance mechanism, as higher leverage imposes discipline on the managers and reduces cash flows that the managers can use for agency motivated acquisitions. Thus, we should expect a positive relationship between acquirer abnormal returns and leverage. Moeller et al. (2004) document a negative relationship between acquirer size and acquirer returns. One possible reason is that the size of the acquirer is a deterrent to market discipline. Hence, we should expect a negative relationship between acquirer returns and size.

The second set of controls is deal characteristics. Moeller et al. (2004) document a positive relationship between abnormal returns and deal size. However, it should also be pointed out that Moeller et al. find the reverse relationship in a sub-sample consisting of very large deals. The literature has documented a negative relationship when the acquisition is paid for in equity. The reason is that equity has an adverse selection problem. Thus, we should expect a negative relationship between abnormal returns and equity. To complete the set of controls we also include cash as an additional control. Moeller et al. (2004) find a negative return if the firm acquires a public target the reason is that the private firms command a liquidity premium. Thus, as in the prior literature we add two additional controls public and subsidiary. If two firms which do not belong to the same industry merge then the combined firm becomes a conglomerate. We add a dummy for these types of acquisitions. Recent literature has pointed out that conglomerate acquisitions need not be value destroying thus we expect a positive sign for the estimate. Hence, we create a binary variable for high tech which takes the value of one if both the acquirer and the target are in high technology industries. We expect a positive relationship as the human capital and technology gains may emerge from the acquisition.

Table 5 panel (A) reports a negative relationship of acquirer abnormal return about the announcement of the acquisition. These results are consistent with the findings of Table 4 Panel (A). Similarly, Table 5 Panel (B) reports the results of acquirer announcement day 
Table 5 Regression of abnormal returns to acquirer with controls

\begin{tabular}{|c|c|c|c|c|}
\hline 3-day abnormal returns & (1) & $(2)$ & (3) & (4) \\
\hline \multicolumn{5}{|c|}{ Panel A: symmetric non-weighted centrality measures as independent variables ${ }^{\mathrm{a}}$} \\
\hline \multicolumn{5}{|l|}{ Centrality } \\
\hline \multirow[t]{2}{*}{ Degree } & -0.0001 & & & \\
\hline & $2.09 *$ & & & \\
\hline \multirow[t]{2}{*}{ Eigenvector } & & -0.0006 & & \\
\hline & & $2.79 * *$ & & \\
\hline \multirow[t]{2}{*}{ Closeness } & & & -0.0002 & \\
\hline & & & $3.21 * *$ & \\
\hline \multirow[t]{2}{*}{ Betweenness } & & & & -0.0038 \\
\hline & & & & $3.28 * *$ \\
\hline \multicolumn{5}{|l|}{ Firm characteristics } \\
\hline \multirow[t]{2}{*}{ Tobin's Q } & -0.0008 & -0.0008 & -0.0008 & -0.0008 \\
\hline & $2.42 *$ & $2.35^{*}$ & $2.37 *$ & $2.34^{*}$ \\
\hline \multirow[t]{2}{*}{ Cash flows } & -0.0098 & -0.0119 & -0.0122 & -0.0113 \\
\hline & $2.25^{*}$ & $2.64 * *$ & $2.69 * *$ & $2.53^{*}$ \\
\hline \multirow[t]{2}{*}{ Leverage } & 0.0003 & 0.0007 & 0.0012 & 0.0008 \\
\hline & 0.07 & 0.19 & 0.34 & 0.22 \\
\hline \multirow[t]{2}{*}{ Size } & -0.0001 & -0.0001 & -0.0001 & -0.0001 \\
\hline & $4.12 * *$ & $3.75 * *$ & $3.61 * *$ & $3.85 * *$ \\
\hline \multicolumn{5}{|l|}{ Deal characteristics } \\
\hline \multirow[t]{2}{*}{ Deal size } & 0.0020 & 0.0054 & 0.0053 & 0.0054 \\
\hline & 1.86 & $2.03 *$ & $2.02 *$ & $2.04 *$ \\
\hline \multirow[t]{2}{*}{ Tender } & 0.0123 & 0.0124 & 0.0123 & 0.0126 \\
\hline & $3.39 * *$ & $3.28 * *$ & $3.25 * *$ & $3.33^{* *}$ \\
\hline \multirow[t]{2}{*}{ All equity } & -0.0030 & -0.0009 & -0.0011 & -0.0010 \\
\hline & 1.37 & 0.36 & 0.41 & 0.39 \\
\hline \multirow[t]{2}{*}{ All cash } & 0.0022 & 0.0030 & 0.0029 & 0.0029 \\
\hline & 1.54 & $2.03 *$ & $1.96^{*}$ & $1.98^{*}$ \\
\hline \multirow[t]{2}{*}{ Friendly } & -0.0441 & -0.0469 & -0.0466 & -0.0469 \\
\hline & $3.47 * *$ & $3.52 * *$ & $3.50^{* *}$ & $3.51 * *$ \\
\hline \multirow[t]{2}{*}{ Hostile } & -0.0554 & -0.0601 & -0.0598 & -0.0600 \\
\hline & $3.61 * *$ & $3.77 * *$ & $3.75 * *$ & $3.76 * *$ \\
\hline \multirow[t]{2}{*}{ Public target } & -0.0252 & -0.0271 & -0.0271 & -0.0270 \\
\hline & $13.91 * *$ & $13.38 * *$ & $13.36^{* *}$ & $13.30^{* *}$ \\
\hline \multirow[t]{2}{*}{ Subsidiary target } & 0.0038 & 0.0035 & 0.0034 & 0.0038 \\
\hline & $2.50 *$ & $2.19 *$ & $2.16^{*}$ & $2.42 *$ \\
\hline \multirow[t]{2}{*}{ Conglomerate } & 0.0008 & 0.0007 & 0.0006 & 0.0009 \\
\hline & 0.64 & 0.49 & 0.43 & 0.66 \\
\hline \multirow[t]{2}{*}{ High tech } & -0.0010 & 0.0013 & 0.0015 & 0.0010 \\
\hline & 0.64 & 0.81 & 0.93 & 0.66 \\
\hline \multicolumn{5}{|l|}{ Industry } \\
\hline \multirow[t]{2}{*}{ Product market competition } & 0.0008 & -0.0032 & -0.0030 & -0.0037 \\
\hline & 0.25 & 0.98 & 0.93 & 1.12 \\
\hline
\end{tabular}


Table 5 continued

\begin{tabular}{cllll}
\hline 3-day abnormal returns & $(1)$ & $(2)$ & $(3)$ & $(4)$ \\
\hline Tobin's Q & 0.0004 & 0.0009 & 0.0009 & 0.0009 \\
& 1.25 & $2.16^{*}$ & $2.18^{*}$ & $2.20^{*}$ \\
Cash flow & -0.0004 & -0.0010 & -0.0007 & -0.0009 \\
& 0.05 & 0.14 & 0.10 & 0.13 \\
Leverage & 0.0030 & 0.0002 & 0.0006 & 0.0006 \\
Size & 0.77 & 0.06 & 0.17 & 0.15 \\
& 0.0001 & 0.0001 & 0.0001 & 0.0001 \\
Constant & 0.25 & 0.33 & 0.28 & 0.20 \\
& 0.0663 & 0.0664 & 0.0671 & 0.0625 \\
Observations & $3.60^{* *}$ & $3.50^{* *}$ & $3.54^{* *}$ & $3.32^{* *}$ \\
$R^{2}$ & 15,378 & 15,378 & 15,378 & 15,378 \\
& 0.03 & 0.03 & 0.03 & 0.03
\end{tabular}

Panel B: weighted centrality measures as independent variables ${ }^{b}$

Symmetric centrality

$\begin{array}{ll}\text { Degree weighted } & -0.0109 \\ & 4.63^{* *}\end{array}$

Eigenvector weighted

$-0.0002$

$5.29 * *$

Directed centrality

In-degree

$-0.0107$

$2.26 *$

Out-degree

$-0.0183$

$5.86^{* *}$

Firm characteristics

\begin{tabular}{lllll} 
Tobin's Q & -0.0008 & -0.0008 & -0.0008 & -0.0008 \\
Cash flows & $2.45^{*}$ & $2.46^{*}$ & $2.36^{*}$ & $2.47^{*}$ \\
Leverage & -0.0131 & -0.0134 & -0.0119 & -0.0137 \\
Size & $2.88^{* *}$ & $2.93^{* *}$ & $2.64^{* *}$ & $3.00^{* *}$ \\
& 0.0023 & 0.0033 & 0.0009 & 0.0033 \\
Deal characteristics & 0.68 & 0.95 & 0.26 & 0.96 \\
Deal size & -0.0001 & -0.0001 & -0.0001 & -0.0001 \\
Tender & $3.81^{* *}$ & $3.75^{* *}$ & $3.86^{* *}$ & $3.78^{* *}$ \\
All equity & & & & 0.0053 \\
All cash & 0.0053 & 0.0053 & 0.0054 & $2.02^{*}$ \\
Friendly & $2.02^{*}$ & $2.02^{*}$ & $2.03^{*}$ & 0.0120 \\
& 0.0123 & 0.0124 & 0.0127 & $3.19^{* *}$ \\
& $3.26 * *$ & $3.29 * *$ & $3.36^{* *}$ & -0.0012 \\
& -0.0011 & -0.0012 & -0.0011 & 0.48 \\
& 0.45 & 0.49 & 0.42 & 0.0026 \\
\hline
\end{tabular}


Table 5 continued

\begin{tabular}{|c|c|c|c|c|}
\hline 3-day abnormal returns & (1) & (2) & (3) & (4) \\
\hline \multirow[t]{2}{*}{ Hostile } & -0.0594 & -0.0594 & -0.0594 & -0.0598 \\
\hline & $3.72 * *$ & $3.72 * *$ & $3.72 * *$ & $3.75 * *$ \\
\hline \multirow[t]{2}{*}{ Public target } & -0.0270 & -0.0271 & -0.0271 & -0.0270 \\
\hline & $13.36^{* *}$ & $13.37 * *$ & $13.40 * *$ & $13.34 * *$ \\
\hline \multirow[t]{2}{*}{ Subsidiary target } & 0.0035 & 0.0036 & 0.0036 & 0.0034 \\
\hline & $2.20 *$ & $2.26^{*}$ & $2.25^{*}$ & $2.16^{*}$ \\
\hline \multirow[t]{2}{*}{ Conglomerate } & 0.0008 & 0.0009 & 0.0007 & 0.0007 \\
\hline & 0.58 & 0.66 & 0.50 & 0.54 \\
\hline \multirow[t]{2}{*}{ High tech } & 0.0026 & 0.0027 & 0.0010 & 0.0031 \\
\hline & 1.57 & 1.67 & 0.62 & 1.89 \\
\hline \multicolumn{5}{|l|}{ Industry } \\
\hline \multirow[t]{2}{*}{ Product market competition } & -0.0027 & -0.0026 & -0.0032 & -0.0021 \\
\hline & 0.84 & 0.78 & 0.98 & 0.65 \\
\hline \multirow[t]{2}{*}{ Tobin's Q } & 0.0009 & 0.0009 & 0.0009 & 0.0009 \\
\hline & $2.06^{*}$ & $2.10^{*}$ & $2.13^{*}$ & $2.06^{*}$ \\
\hline \multirow[t]{2}{*}{ Cash flow } & -0.0018 & -0.0016 & -0.0014 & -0.0019 \\
\hline & 0.25 & 0.24 & 0.20 & 0.27 \\
\hline \multirow[t]{2}{*}{ Leverage } & -0.0001 & 0.0001 & 0.0003 & -0.0003 \\
\hline & 0.00 & 0.04 & 0.09 & 0.09 \\
\hline \multirow[t]{2}{*}{ Size } & 0.0001 & 0.0001 & 0.0001 & -0.0001 \\
\hline & 0.07 & 0.13 & 0.41 & 0.42 \\
\hline \multirow[t]{2}{*}{ Constant } & 0.0625 & 0.0610 & 0.0627 & 0.0615 \\
\hline & $3.32 * *$ & $3.24 * *$ & $3.33 * *$ & $3.26 * *$ \\
\hline Observations & 15,378 & 15,378 & 15,378 & 15,378 \\
\hline$R^{2}$ & 0.03 & 0.03 & 0.03 & 0.03 \\
\hline
\end{tabular}

a This table reports the relationship between acquirers abnormal returns and the acquirers non-weighted centrality measures. OLS regression methodology is used with clustered standard errors. The variables are defined in previous tables. The standard errors are clustered at the industry level. Fama-French 49 industries are used. Year and industry dummies have been used but the coefficients are not reported. **, * represents statistical significance at the 1 and $5 \%$ level respectively

b This table reports the relationship between acquirers abnormal returns and the acquirers weighted centrality measures. OLS regression methodology is used with clustered standard errors. The variables are defined in previous tables. The standard errors are clustered at the industry level (Fama-French 49 industries). Year and industry dummies have been used but the coefficients are not reported. **, * represents statistical significance at the 1 and $5 \%$ level respectively

abnormal returns and the weighted centrality measures. The estimates of the variables of interest are negative and statistically significant at the $5 \%$ confidence interval. These results are also consistent with the findings of Table 4 Panel (B). Thus, Table 5 results are consistent with those of Table 4 and show the robustness of the results to inclusion of controls.

In terms of other variables reported in Table 5, we find that the acquirer returns are negatively correlated with the Acquirers' Tobin Q, cash flows and size. The reason seems to be that high growth firms measured by higher Tobin's Q usually use more stocks in their payment and so result in lower Tobin's Q. if the acquirer has poor cash flows and so is 
Table 6 Regression of 5 day abnormal returns to acquirer with industry controls weighted centrality measures

\begin{tabular}{ll}
\hline 5 -day abnormal returns & $(1)$ \\
\hline Symmetric centrality & \\
Degree weighted & -0.0199 \\
& $3.21^{* *}$
\end{tabular}

Eigenvector weighted

$-0.0002$

$2.47 *$

Directed centrality

In-degree

$-0.0272$

$2.43 *$

Out-degree

$-0.0230$

$2.93 * *$

Firm characteristics

\begin{tabular}{|c|c|c|c|c|}
\hline \multirow[t]{2}{*}{ Tobin's Q } & -0.0010 & -0.0010 & -0.0010 & -0.0010 \\
\hline & $2.40 *$ & $2.38^{*}$ & $2.40 *$ & $2.39 *$ \\
\hline \multirow[t]{2}{*}{ Cash flows } & -0.0179 & -0.0178 & -0.0179 & -0.0178 \\
\hline & $2.91 * *$ & $2.90 * *$ & $2.90 * *$ & $2.89 * *$ \\
\hline \multirow[t]{2}{*}{ Leverage } & 0.0036 & 0.0042 & 0.0030 & 0.0039 \\
\hline & 0.80 & 0.90 & 0.65 & 0.85 \\
\hline \multirow[t]{2}{*}{ Size } & -0.0001 & -0.0001 & -0.0001 & -0.0001 \\
\hline & $3.13 * *$ & $3.10 * *$ & $3.18 * *$ & $3.08 * *$ \\
\hline \multicolumn{5}{|l|}{ Deal characteristics } \\
\hline \multirow[t]{2}{*}{ Deal size } & 0.0058 & 0.0058 & 0.0058 & 0.0058 \\
\hline & 1.93 & 1.93 & 1.92 & 1.93 \\
\hline \multirow[t]{2}{*}{ Tender } & 0.0124 & 0.0126 & 0.0124 & 0.0125 \\
\hline & $2.90 * *$ & $2.96 * *$ & $2.89 * *$ & $2.93 * *$ \\
\hline \multirow[t]{2}{*}{ All equity } & 0.0006 & 0.0006 & 0.0006 & 0.0007 \\
\hline & 0.21 & 0.20 & 0.21 & 0.22 \\
\hline \multirow[t]{2}{*}{ All cash } & 0.0010 & 0.0010 & 0.0011 & 0.0010 \\
\hline & 0.57 & 0.57 & 0.64 & 0.56 \\
\hline \multirow[t]{2}{*}{ Friendly } & -0.0510 & -0.0510 & -0.0510 & -0.0511 \\
\hline & $3.76^{* *}$ & $3.76^{* *}$ & $3.77 * *$ & $3.76^{* *}$ \\
\hline \multirow[t]{2}{*}{ Hostile } & -0.0679 & -0.0680 & -0.0678 & -0.0681 \\
\hline & $4.14 * *$ & $4.14 * *$ & $4.13 * *$ & $4.14 * *$ \\
\hline \multirow[t]{2}{*}{ Public target } & -0.0294 & -0.0296 & -0.0295 & -0.0295 \\
\hline & $12.29 * *$ & $12.34 * *$ & $12.30 * *$ & $12.31 * *$ \\
\hline \multirow[t]{2}{*}{ Subsidiary target } & 0.0024 & 0.0025 & 0.0024 & 0.0024 \\
\hline & 1.28 & 1.31 & 1.27 & 1.27 \\
\hline \multirow[t]{2}{*}{ Conglomerate } & -0.0002 & -0.0003 & -0.0005 & -0.0002 \\
\hline & 0.14 & 0.15 & 0.28 & 0.10 \\
\hline \multirow[t]{2}{*}{ High tech } & 0.0018 & 0.0017 & 0.0015 & 0.0020 \\
\hline & 0.63 & 0.59 & 0.54 & 0.69 \\
\hline \multicolumn{5}{|l|}{ Industry } \\
\hline \multirow[t]{2}{*}{ Product market competition } & -0.0047 & -0.0038 & -0.0042 & -0.0043 \\
\hline & 1.18 & 0.96 & 1.06 & 1.07 \\
\hline
\end{tabular}


Table 6 continued

\begin{tabular}{lllll}
\hline 5-day abnormal returns & $(1)$ & $(2)$ & $(3)$ & $(4)$ \\
\hline Tobin's Q & 0.0006 & 0.0006 & 0.0006 & 0.0006 \\
Cash flow & 1.40 & 1.42 & 1.37 & 1.41 \\
& -0.0041 & -0.0039 & -0.0043 & -0.0039 \\
Leverage & 0.62 & 0.60 & 0.66 & 0.59 \\
& -0.0068 & -0.0065 & -0.0071 & -0.0067 \\
Size & 1.54 & 1.46 & 1.62 & 1.52 \\
& 0.0001 & 0.0001 & 0.0001 & 0.0001 \\
Constant & 0.16 & 0.21 & 0.47 & 0.06 \\
& 0.0646 & 0.0621 & 0.0642 & 0.0640 \\
Observations & $2.26^{*}$ & $2.17^{*}$ & $2.24 *$ & $2.24^{*}$ \\
$R^{2}$ & 15,378 & 15,378 & 15,378 & 15,378 \\
\hline
\end{tabular}

This table reports the relationship between acquirers abnormal returns and the acquirers weighted centrality measures. OLS regression methodology is used with clustered standard errors. The variables are defined in previous tables. The standard errors are clustered at the industry level. Fama-French 49 industries are used. Year and industry dummies have been used but the coefficients are not reported. **, * represents statistical significance at the 1 and $5 \%$ level respectively

more likely to have agency problems and so the negative relationship between cash flows and abnormal returns. Acquisitions by younger firms also lead to negative abnormal returns as these are more likely to be risky. The sign and the significance of the estimates of the deal characteristics are also similar to those in the literature. For example, a hostile offer leads to lower abnormal returns for the acquirer.

A robustness test for the above results is to use a different dependent variable. So, instead of the 3 day-abnormal returns we sue the 5-day announcement day abnormal returns. We replicate one of our panels Table $5 \mathrm{~b}$ other panels have been replicated but not reported. The results in Table 6 report that the estimated coefficient of 5-day abnormal returns and weighted centrality measures is negative and statistically significant at the $5 \%$ confidence level. These results show that our estimates of the Table 5 panel (b) are robust to changes in the event window.

Tables 4, 5 and 6 report a negative relationship between the acquirer's announcement day abnormal returns and the acquirer's centrality measures. These results suggest that the market believes that the acquisition by firms that are more central reduces the acquirers' value. One reason for this value reduction is that the acquirer might be paying too much premium. This maybe the case if the target is better informed about the acquirer than the acquirer is about the target. This informational difference leads the target to get a better deal from the acquirer.

\subsection{Acquirers centrality and its interaction with information}

In this section we investigate the returns to the acquirer if there is a difference in information availability of the acquirer and the target. One way of investigating this would be to include the distance between the centrality measures of the acquirer and the target. However, the strand of the literature on horizontal acquisitions suggests that a significant 
Table 7 Regression of 3 day abnormal returns to acquirer with proxies for information

\begin{tabular}{ll}
\hline 3-day abnormal returns & $(1)$ \\
\hline Panel A: public targets $^{\mathrm{a}}$ & \\
Symmetric centrality & -0.0223 \\
Degree weighted & $4.09^{* *}$ \\
& 0.0312 \\
Degree weighted* public target & $4.97^{* *}$
\end{tabular}

Eigenvector weighted

$-0.0003$

$3.58 * *$

Eigenvector weighted* public target

0.0005

$4.33 * *$

Directed centrality

In-degree

$-0.0327$

$3.24 * *$

In-degree* public target

0.0537

$4.69 * *$

Out-degree

$-0.0257$

$3.81 * *$

Out-degree* public target

0.0413

$4.52 * *$

Firm characteristics

\begin{tabular}{|c|c|c|c|c|}
\hline \multirow[t]{2}{*}{ Tobin's Q } & -0.0008 & -0.0008 & -0.0008 & -0.0008 \\
\hline & $2.39 *$ & $2.38^{*}$ & $2.41^{*}$ & $2.37 *$ \\
\hline \multirow[t]{2}{*}{ Cash flows } & -0.0173 & -0.0173 & -0.0172 & -0.0173 \\
\hline & $3.66 * *$ & $3.66^{* *}$ & $3.63 * *$ & $3.65^{* *}$ \\
\hline \multirow[t]{2}{*}{ Leverage } & 0.0027 & 0.0030 & 0.0016 & 0.0030 \\
\hline & 0.68 & 0.74 & 0.40 & 0.76 \\
\hline \multirow[t]{2}{*}{ Size } & -0.0001 & -0.0001 & -0.0001 & -0.0001 \\
\hline & $3.04 * *$ & $3.02 * *$ & $3.03 * *$ & $2.98 * *$ \\
\hline \multicolumn{5}{|c|}{ Deal characteristics } \\
\hline \multirow[t]{2}{*}{ Deal size } & 0.0052 & 0.0052 & 0.0052 & 0.0052 \\
\hline & $1.98 *$ & $1.98 *$ & $1.98 *$ & $1.99 *$ \\
\hline \multirow[t]{2}{*}{ Tender } & 0.0116 & 0.0113 & 0.0107 & 0.0119 \\
\hline & $3.06^{* *}$ & $2.99 * *$ & $2.83 * *$ & $3.16^{* *}$ \\
\hline \multirow[t]{2}{*}{ All equity } & -0.0008 & -0.0009 & -0.0008 & -0.0008 \\
\hline & 0.31 & 0.34 & 0.31 & 0.32 \\
\hline \multirow[t]{2}{*}{ All cash } & 0.0027 & 0.0028 & 0.0029 & 0.0027 \\
\hline & 1.84 & 1.88 & 1.93 & 1.82 \\
\hline \multirow[t]{2}{*}{ Friendly } & -0.0455 & -0.0454 & -0.0459 & -0.0453 \\
\hline & $3.54 * *$ & $3.53 * *$ & $3.59 * *$ & $3.49 * *$ \\
\hline \multirow[t]{2}{*}{ Hostile } & -0.0583 & -0.0580 & -0.0589 & -0.0579 \\
\hline & $3.78 * *$ & $3.76^{* *}$ & $3.83 * *$ & $3.73^{* *}$ \\
\hline \multirow[t]{2}{*}{ Public target } & -0.0355 & -0.0342 & -0.0342 & -0.0341 \\
\hline & $12.95 * *$ & $12.79 * *$ & $12.59 * *$ & $13.20 * *$ \\
\hline
\end{tabular}


Table 7 continued

\begin{tabular}{|c|c|c|c|c|}
\hline 3-day abnormal returns & (1) & (2) & (3) & (4) \\
\hline \multirow[t]{2}{*}{ Conglomerate } & 0.0008 & 0.0008 & 0.0006 & 0.0008 \\
\hline & 0.57 & 0.53 & 0.42 & 0.58 \\
\hline \multirow[t]{2}{*}{ High tech } & 0.0025 & 0.0024 & 0.0023 & 0.0026 \\
\hline & 1.02 & 0.97 & 0.94 & 1.08 \\
\hline \multicolumn{5}{|l|}{ Industry } \\
\hline \multirow[t]{2}{*}{ Product market competition } & -0.0019 & -0.0014 & -0.0019 & -0.0014 \\
\hline & 0.54 & 0.40 & 0.54 & 0.42 \\
\hline \multirow[t]{2}{*}{ Tobin's Q } & 0.0009 & 0.0009 & 0.0008 & 0.0009 \\
\hline & $1.99 *$ & $1.99 *$ & 1.94 & $2.00 *$ \\
\hline \multirow[t]{2}{*}{ Cash flow } & -0.0054 & -0.0054 & -0.0057 & -0.0053 \\
\hline & 0.75 & 0.74 & 0.79 & 0.73 \\
\hline \multirow[t]{2}{*}{ Leverage } & -0.0049 & -0.0046 & -0.0053 & -0.0049 \\
\hline & 1.37 & 1.28 & 1.49 & 1.35 \\
\hline \multirow[t]{2}{*}{ Size } & -0.0001 & -0.0001 & -0.0001 & -0.0001 \\
\hline & 0.47 & 0.42 & 0.23 & 0.48 \\
\hline \multirow[t]{2}{*}{ Constant } & 0.0564 & 0.0545 & 0.0565 & 0.0557 \\
\hline & $2.39 *$ & $2.31 *$ & $2.38 *$ & $2.37 *$ \\
\hline Observations & 15,378 & 15,378 & 15,378 & 15,378 \\
\hline$R^{2}$ & 0.04 & 0.04 & 0.04 & 0.04 \\
\hline \multicolumn{5}{|c|}{ Panel B: size of targets (natural log of transaction value) ${ }^{b}$} \\
\hline \multicolumn{5}{|l|}{ Symmetric centrality } \\
\hline \multirow[t]{2}{*}{ Degree weighted } & -0.0348 & & & \\
\hline & $4.73 * *$ & & & \\
\hline \multirow[t]{2}{*}{ Degree weighted* size of target } & 0.0051 & & & \\
\hline & $3.72 * *$ & & & \\
\hline \multirow[t]{2}{*}{ Eigenvector weighted } & & -0.0006 & & \\
\hline & & $4.83 * *$ & & \\
\hline \multirow[t]{2}{*}{ Eigenvector weighted ${ }^{*}$ size of target } & & 0.0001 & & \\
\hline & & $4.11 * *$ & & \\
\hline \multicolumn{5}{|l|}{ Directed centrality } \\
\hline \multirow[t]{2}{*}{ In-degree } & & & -0.0573 & \\
\hline & & & $3.95 * *$ & \\
\hline \multirow[t]{2}{*}{ In-degree* size of target } & & & 0.0097 & \\
\hline & & & $3.46^{* *}$ & \\
\hline \multirow[t]{2}{*}{ Out-degree } & & & & -0.0419 \\
\hline & & & & $4.43 * *$ \\
\hline \multirow[t]{2}{*}{ Out-degree* size of target } & & & & 0.0061 \\
\hline & & & & $3.50 * *$ \\
\hline \multicolumn{5}{|l|}{ Firm characteristics } \\
\hline \multirow[t]{2}{*}{ Tobin's Q } & -0.0007 & -0.0007 & -0.0007 & -0.0007 \\
\hline & $1.98 *$ & $1.97 *$ & $1.98 *$ & $2.00 *$ \\
\hline \multirow[t]{2}{*}{ Cash flows } & -0.0152 & -0.0152 & -0.0152 & -0.0153 \\
\hline & $3.20 * *$ & $3.20 * *$ & $3.18 * *$ & $3.21 * *$ \\
\hline
\end{tabular}


Table 7 continued

\begin{tabular}{|c|c|c|c|c|}
\hline 3-day abnormal returns & (1) & (2) & (3) & (4) \\
\hline \multirow[t]{2}{*}{ Leverage } & 0.0026 & 0.0032 & 0.0022 & 0.0028 \\
\hline & 0.67 & 0.81 & 0.56 & 0.72 \\
\hline \multirow[t]{2}{*}{ Size } & -0.0000 & -0.0000 & -0.0000 & -0.0000 \\
\hline & 1.77 & 1.83 & 1.79 & 1.58 \\
\hline \multicolumn{5}{|l|}{ Deal characteristics } \\
\hline \multirow[t]{2}{*}{ Size of target } & -0.0030 & -0.0029 & -0.0029 & -0.0027 \\
\hline & $4.32 * *$ & $4.40 * *$ & $4.26 * *$ & $4.19 * *$ \\
\hline \multirow[t]{2}{*}{ Deal size } & 0.0053 & 0.0054 & 0.0054 & 0.0054 \\
\hline & $2.01 *$ & $2.01 *$ & $2.01 *$ & $2.02 *$ \\
\hline \multirow[t]{2}{*}{ Tender } & 0.0107 & 0.0110 & 0.0105 & 0.0108 \\
\hline & $2.86^{* *}$ & $2.93 * *$ & $2.82^{* *}$ & $2.89 * *$ \\
\hline \multirow[t]{2}{*}{ All equity } & -0.0001 & -0.0002 & -0.0001 & -0.0002 \\
\hline & 0.05 & 0.07 & 0.04 & 0.07 \\
\hline \multirow[t]{2}{*}{ All cash } & 0.0027 & 0.0027 & 0.0028 & 0.0027 \\
\hline & 1.81 & 1.80 & 1.83 & 1.77 \\
\hline \multirow[t]{2}{*}{ Friendly } & -0.0457 & -0.0458 & -0.0457 & -0.0459 \\
\hline & $3.57 * *$ & $3.58 * *$ & $3.59 * *$ & $3.56 * *$ \\
\hline \multirow[t]{2}{*}{ Hostile } & -0.0562 & -0.0562 & -0.0565 & -0.0560 \\
\hline & $3.67 * *$ & $3.68 * *$ & $3.71 * *$ & $3.64 * *$ \\
\hline \multirow[t]{2}{*}{ Public target } & -0.0227 & -0.0228 & -0.0229 & -0.0227 \\
\hline & $10.78 * *$ & $10.81 * *$ & $10.83 * *$ & $10.77 * *$ \\
\hline \multirow[t]{2}{*}{ Segment target } & 0.0037 & 0.0038 & 0.0037 & 0.0037 \\
\hline & $2.26^{*}$ & $2.30 *$ & $2.27 *$ & $2.27 *$ \\
\hline \multirow[t]{2}{*}{ Conglomerate } & 0.0008 & 0.0008 & 0.0006 & 0.0009 \\
\hline & 0.54 & 0.57 & 0.41 & 0.60 \\
\hline \multirow[t]{2}{*}{ High tech } & 0.0022 & 0.0020 & 0.0021 & 0.0023 \\
\hline & 0.89 & 0.83 & 0.85 & 0.94 \\
\hline \multicolumn{5}{|l|}{ Industry } \\
\hline \multirow[t]{2}{*}{ Product market competition } & -0.0024 & -0.0017 & -0.0020 & -0.0020 \\
\hline & 0.68 & 0.49 & 0.59 & 0.59 \\
\hline \multirow[t]{2}{*}{ Tobin's Q } & 0.0009 & 0.0009 & 0.0009 & 0.0009 \\
\hline & $2.00 *$ & $2.02 *$ & $2.00 *$ & $2.00 *$ \\
\hline \multirow[t]{2}{*}{ Cash flow } & -0.0054 & -0.0053 & -0.0054 & -0.0052 \\
\hline & 0.75 & 0.73 & 0.76 & 0.72 \\
\hline \multirow[t]{2}{*}{ Leverage } & -0.0050 & -0.0045 & -0.0053 & -0.0049 \\
\hline & 1.38 & 1.23 & 1.47 & 1.33 \\
\hline \multirow[t]{2}{*}{ Size } & -0.0000 & -0.0000 & -0.0000 & -0.0000 \\
\hline & 0.18 & 0.19 & 0.08 & 0.15 \\
\hline \multirow[t]{2}{*}{ Constant } & 0.0642 & 0.0620 & 0.0633 & 0.0632 \\
\hline & $2.73 * *$ & $2.63 * *$ & $2.70 * *$ & $2.69 * *$ \\
\hline
\end{tabular}


Table 7 continued

\begin{tabular}{lllll}
\hline 3-day abnormal returns & $(1)$ & $(2)$ & $(3)$ & $(4)$ \\
\hline Observations & 15,378 & 15,378 & 15,378 & 15,378 \\
$R^{2}$ & 0.04 & 0.04 & 0.04 & 0.04 \\
\hline
\end{tabular}

${ }^{a}$ This table reports the relationship between acquirers abnormal returns and the acquirers weighted centrality measures. OLS regression methodology is used with clustered standard errors. The variables are defined in previous tables. The standard errors are clustered at the industry level. Fama-French 49 industries are used. Year and industry dummies have been used but the coefficients are not reported. **, * represents statistical significance at the 1 and $5 \%$ level respectively

b This table reports the relationship between acquirers abnormal returns and the acquirers weighted centrality measures. OLS regression methodology is used with clustered standard errors. The variables are defined in previous tables. The standard errors are clustered at the industry level. Fama-French 49 industries are used. Year and industry dummies have been used but the coefficients are not reported. **, * represents statistical significance at the 1 and $5 \%$ level respectively

number of these acquisitions should be in the same industry. Now, the centrality measures used in this research are those of the industry, thus using the centrality measures of the target and the acquirer will not disentangle these effects as both the acquirer and the target will have the same centrality measure.

To resolve this empirical issue, we looked at the data available in SDC. SDC in general classifies almost all the targets as public or private. From this research's point of view this classification is beneficial as public targets tend to have far more information flow available than private targets. Another variable that is available for almost all the targets is the transaction value. Here the implication for our research is that targets that are larger will have more information available than smaller targets. We exploit this data availability in hypothesis (2).

We test hypothesis (2) by using equation (1) but augmenting it with an interaction term between centrality and the information availability of the target. Table 7 panel (a) interacts the centrality measure with the public status of the target; while panel (b) interacts the centrality measure with the size of the target.

The results reported in Table 7 panel (a) report that the estimates of 3-day abnormal returns and weighted centrality measure are negative and statistically significant at the once percent confidence level. These results are consistent with findings of Table 5b. The interaction term of weighted centrality and Public Target is positive and statistically significant at the $1 \%$ confidence interval. This result suggests that the announcement day abnormal returns increases for the acquirer if the target is publicly traded and is relative to the acquirer's centrality measure. The sign and the statistical significance of the other variables are similar to those reported in Table $5 \mathrm{~b}$.

Table 7 panel (b) reports the estimates of the acquirer abnormal returns and interaction term of the weighted centrality measure of the acquirer and the size of the target. The estimates of the interaction term are positive and statistically significant at the $1 \%$ confidence interval. These results are consistent with the findings of the Table $7 \mathrm{a}$.

The implication of these results is as follows. The positive estimate suggests that as the weighted degree of the acquirer increases and the size of the target (or the target's public status) increases, then the acquirer's abnormal returns increases. This provides support for the second hypothesis that the abnormal returns to the acquirer which is more central in a network increases if the target is public and is larger in size. 
Table 8 Regression of target stock premium and target weighted centrality measures

\begin{tabular}{ll}
\hline Markup + runup & $(1)$ \\
\hline Panel A: stock market premium & \\
Symmetric centrality & \\
Degree weighted & -0.1153 \\
& $2.62^{* *}$
\end{tabular}

Eigenvector weighted

$-0.0023$

$3.27 * *$

Directed centrality

In-degree

$-0.0578$

$1.98 *$

Out-degree

$-0.1880$

$2.94 * *$

Firm characteristics

\begin{tabular}{|c|c|c|c|c|}
\hline \multirow[t]{2}{*}{ Tobin's Q } & -0.0177 & -0.0168 & -0.0183 & -0.0168 \\
\hline & $4.03 * *$ & $4.21 * *$ & $4.08 * *$ & $3.56^{* *}$ \\
\hline \multirow[t]{2}{*}{ Cash flows } & 0.0969 & 0.1044 & 0.0878 & 0.0862 \\
\hline & 1.72 & $2.01 *$ & 1.48 & 1.39 \\
\hline \multirow[t]{2}{*}{ Leverage } & -0.0851 & -0.0702 & -0.1025 & -0.0741 \\
\hline & 1.36 & 1.22 & 1.58 & 1.09 \\
\hline \multirow[t]{2}{*}{ Size } & -0.0001 & -0.0001 & -0.0001 & -0.0001 \\
\hline & 0.17 & 0.33 & 0.19 & 0.27 \\
\hline \multicolumn{5}{|l|}{ Deal characteristics } \\
\hline \multirow[t]{2}{*}{ Deal size } & -0.0263 & -0.0248 & -0.0254 & -0.0270 \\
\hline & $2.12 *$ & $2.19^{*}$ & $1.97 *$ & $2.02 *$ \\
\hline \multirow[t]{2}{*}{ Tender } & 0.0853 & 0.0957 & 0.0972 & 0.0884 \\
\hline & $2.88^{* *}$ & $3.57 * *$ & $3.19 * *$ & $2.77 * *$ \\
\hline \multirow[t]{2}{*}{ All equity } & -0.0041 & 0.0070 & -0.0027 & 0.0060 \\
\hline & 0.19 & 0.35 & 0.12 & 0.25 \\
\hline \multirow[t]{2}{*}{ All cash } & 0.0058 & 0.0066 & -0.0016 & 0.0072 \\
\hline & 0.22 & 0.28 & 0.06 & 0.25 \\
\hline \multirow[t]{2}{*}{ Friendly } & 0.0205 & 0.0166 & 0.0165 & 0.0195 \\
\hline & 0.70 & 0.63 & 0.55 & 0.62 \\
\hline \multirow[t]{2}{*}{ Hostile } & 0.1796 & 0.1723 & 0.2282 & 0.1790 \\
\hline & 1.91 & $2.02 *$ & $2.30^{*}$ & 1.78 \\
\hline \multirow[t]{2}{*}{ Public target } & 0.2825 & 0.2849 & 0.3396 & 0.2782 \\
\hline & $2.53^{*}$ & $2.81 * *$ & $2.91 * *$ & $2.33 *$ \\
\hline \multirow[t]{2}{*}{ Subsidiary target } & 0.0314 & 0.0252 & 0.0189 & 0.0051 \\
\hline & 0.33 & 0.29 & 0.19 & 0.05 \\
\hline \multirow[t]{2}{*}{ Conglomerate } & 0.0284 & 0.0179 & 0.0045 & -0.0198 \\
\hline & 0.25 & 0.18 & 0.04 & 0.16 \\
\hline \multirow[t]{2}{*}{ High tech } & -0.0368 & -0.0241 & -0.0536 & -0.0227 \\
\hline & 1.39 & 1.00 & $2.00 *$ & 0.80 \\
\hline
\end{tabular}


Table 8 continued

\begin{tabular}{|c|c|c|c|c|}
\hline Markup + runup & (1) & $(2)$ & (3) & (4) \\
\hline \multicolumn{5}{|l|}{ Industry } \\
\hline \multirow[t]{2}{*}{ Product market competition } & 0.0785 & 0.0987 & 0.1067 & 0.0946 \\
\hline & 1.54 & $2.15^{*}$ & $2.04 *$ & 1.74 \\
\hline \multirow[t]{2}{*}{ Tobin's Q } & 0.0094 & 0.0095 & 0.0112 & 0.0124 \\
\hline & 0.78 & 0.89 & 0.90 & 0.99 \\
\hline \multirow[t]{2}{*}{ Cash flow } & 0.0055 & -0.0118 & 0.0118 & 0.0063 \\
\hline & 0.10 & 0.24 & 0.21 & 0.11 \\
\hline \multirow[t]{2}{*}{ Leverage } & -0.0188 & -0.0198 & -0.0194 & -0.0191 \\
\hline & $6.05 * *$ & $7.04 * *$ & $6.03 * *$ & $5.65 * *$ \\
\hline \multirow[t]{2}{*}{ Size } & -0.0001 & -0.0001 & -0.0001 & -0.0001 \\
\hline & 1.33 & 1.63 & 1.51 & 1.85 \\
\hline \multirow[t]{2}{*}{ Constant } & 0.2501 & 0.2470 & 0.1911 & 0.2552 \\
\hline & 1.44 & 1.56 & 1.05 & 1.36 \\
\hline Observations & 2,234 & 2,234 & 2,234 & 2,234 \\
\hline$R^{2}$ & 0.04 & 0.04 & 0.04 & 0.04 \\
\hline Premium & (1) & (2) & (3) & (4) \\
\hline
\end{tabular}

Panel B: valuation premium ${ }^{\mathrm{b}}$

Symmetric centrality

Degree weighted

Eigenvector weighted

In-degree

Out-degree

Firm characteristics

\begin{tabular}{lllll} 
Tobin's Q & -0.0001 & -0.0001 & -0.0001 & -0.0001 \\
Cash flows & 0.97 & 0.66 & 0.84 & 0.79 \\
& 0.0002 & 0.0002 & 0.0002 & 0.0002 \\
Leverage & $3.86^{* *}$ & $3.35^{* *}$ & $3.58^{* *}$ & $4.51^{* *}$ \\
& 0.0001 & 0.0002 & 0.0001 & 0.0002 \\
Size & $2.25^{*}$ & $2.18^{*}$ & 1.73 & $2.79^{* *}$ \\
& -0.0001 & -0.0001 & -0.0001 & -0.0001 \\
Deal characteristics & 0.52 & 0.42 & 0.45 & 0.60 \\
Deal size & & & & 0.0001 \\
& 0.0001 & 0.0001 & 0.0001 & 0.85 \\
Tender & 0.88 & 0.69 & 0.83 & 0.0001 \\
& 0.0001 & 0.0001 & 0.0001 & $5.18^{* *}$ \\
\hline
\end{tabular}

$-0.0001$

$2.23 *$

$-0.0001$

$2.73 * *$

$-0.0001$

$2.09 *$

$-0.0002$

$2.99 * *$

.0001

0002

$51 * *$

0002

0.0001

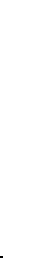


Table 8 continued

\begin{tabular}{|c|c|c|c|c|}
\hline Premium & (1) & (2) & (3) & (4) \\
\hline \multirow[t]{2}{*}{ All equity } & 0.0001 & 0.0001 & -0.0001 & 0.0001 \\
\hline & 0.31 & 0.17 & 0.12 & 0.17 \\
\hline \multirow[t]{2}{*}{ All cash } & -0.0002 & -0.0002 & -0.0002 & -0.0003 \\
\hline & $9.08 * *$ & $7.35^{* *}$ & $7.91 * *$ & $10.39^{* *}$ \\
\hline \multirow[t]{2}{*}{ Friendly } & -0.0002 & -0.0002 & -0.0002 & -0.0002 \\
\hline & $6.96^{* *}$ & $5.42 * *$ & $5.92 * *$ & $7.81^{* *}$ \\
\hline \multirow[t]{2}{*}{ Hostile } & 0.0004 & 0.0004 & 0.0004 & 0.0004 \\
\hline & $3.91 * *$ & $2.95 * *$ & $3.35 * *$ & $4.07 * *$ \\
\hline \multirow[t]{2}{*}{ Public target } & 0.0003 & 0.0003 & 0.0004 & 0.0003 \\
\hline & $2.81 * *$ & $2.15^{*}$ & $2.64 * *$ & $2.89 * *$ \\
\hline \multirow[t]{2}{*}{ Subsidiary target } & 0.0001 & -0.0001 & 0.0001 & 0.0001 \\
\hline & 0.22 & 0.00 & 0.20 & 0.35 \\
\hline \multirow[t]{2}{*}{ Conglomerate } & 0.0001 & -0.0001 & 0.0001 & 0.0001 \\
\hline & 0.25 & 0.03 & 0.07 & 0.15 \\
\hline \multirow[t]{2}{*}{ High tech } & -0.0001 & -0.0001 & -0.0001 & -0.0001 \\
\hline & 1.80 & 1.17 & 1.79 & 1.71 \\
\hline \multicolumn{5}{|l|}{ Industry } \\
\hline \multirow[t]{2}{*}{ Product market competition } & 0.0001 & -0.0001 & 0.0001 & 0.0001 \\
\hline & 0.06 & 0.14 & 0.08 & 0.00 \\
\hline \multirow[t]{2}{*}{ Tobin's Q } & -0.0001 & -0.0001 & -0.0001 & -0.0001 \\
\hline & 0.72 & 0.38 & 0.13 & 0.62 \\
\hline \multirow[t]{2}{*}{ Cash flow } & 0.0001 & -0.0001 & -0.0001 & -0.0001 \\
\hline & 0.16 & 0.02 & 0.03 & 0.16 \\
\hline \multirow[t]{2}{*}{ Leverage } & -0.0001 & -0.0001 & -0.0001 & -0.0001 \\
\hline & $3.25^{* *}$ & $2.49^{*}$ & $2.79 * *$ & $3.69 * *$ \\
\hline \multirow[t]{2}{*}{ Size } & -0.0001 & -0.0001 & -0.0001 & -0.0001 \\
\hline & 1.65 & 1.02 & 1.31 & $2.03 *$ \\
\hline \multirow[t]{2}{*}{ Constant } & 0.0015 & 0.0016 & 0.0015 & 0.0015 \\
\hline & $8.46^{* *}$ & $7.29 * *$ & $7.45^{* *}$ & $9.52 * *$ \\
\hline Observations & 2,234 & 2,234 & 2,234 & 2,234 \\
\hline$R^{2}$ & 0.06 & 0.05 & 0.05 & 0.06 \\
\hline
\end{tabular}

${ }^{a}$ Target variables are used. OLS regression methodology is used with clustered standard errors. The variables are defined in previous tables. The standard errors are clustered at the industry level. Fama-French 49 industries are used. Year and industry dummies have been used but the coefficients are not reported. **, * represents statistical significance at the 1 and $5 \%$ level respectively

b Target premium and the target's weighted centrality measures are used. OLS regression methodology is used with clustered standard errors. The variables are defined in previous tables. The standard errors are clustered at the industry level. Fama-French 49 industries are used. Year and industry dummies have been used but the coefficients are not reported. **, * represents statistical significance at the 1 and $5 \%$ level respectively

\subsection{Target's premium and centrality}

In this sub-section we test the third hypothesis which is that the less central target will receive a larger premium after controlling for other factors. To test the third hypothesis we 
use Eq. (1) instead of using the acquirer values we now use the target values. So, the dependent variable is target premium, and the weighted centrality measures are those of the target.

Table 8 panel (a) reports the estimates of the stock market based premium and the weighted centrality of the target. The estimated coefficient of weighted centrality measures is negative and statistically significant at the $5 \%$ confidence level. Table 8 panel (b) reports the estimates of valuation based premiums and the centrality measure of the target. The reported estimates for the target's weighted centrality are negative and statistically significant at the $5 \%$ confidence interval. These results suggest that as the weighted centrality of the target increases the premium (both stock and valuation) decreases. These results suggest that targets that are more central receive lower premiums. Thus, the findings in this tables support the third hypothesis.

\section{Conclusion}

This paper investigates the relationship between the weighted centrality of acquirers and the returns from the acquisitions. We hypothesize that the more central the firm is the more information is available about the firm, thus giving the other party additional power in bargaining. This bargaining power translates into superior announcement day returns. We use the industry's centrality measure to proxy for the firm's centrality in the network. These measures of centrality include degree, eigenvector, closeness, and betweenness. We find that the abnormal return to the acquirer as measured by the announcement abnormal returns decreases as the acquirer's centrality in the network increases. We also find that the target's premium decreases if it is more central in the network. Finally, we find that the interaction term of the acquirers' centrality and the public status of the target are positive. We interpret this finding to suggest that the central acquirer benefits if it receives more information about the target. We subject the results to a number of robustness tests. These include using directed measures of centrality like in-degree and out-degree. We also use different dependent variables like 3- and 5-days abnormal returns.

We contribute to the growing literature that documents the network centrality and corporate decisions. The literature has studied the impact of the network centrality of the board of directors and CEOs on corporate decisions. We add to that literature by investigating the relationship between customer-supplier network centrality and mergers. We also contribute to the literature that studies the relationship between information and firm value. Here we use the network centrality of the firm as a proxy for information availability. To the best of our knowledge, this is a unique application of the customer-supplier network. In terms of future research, an extension of the paper is to study the choice between cash and stocks used to pay the target when the acquirer is more central.

\section{Appendix}

Centrality Measures (Definitions are based on network theory).

Degree Defined as the number of industries the nodal industry has supplier or customer relationships.

Eigenvector Each node in the industry network is assigned eigen values. Is the sum of the eigenvalues of the connections of the industry. 
Closeness The farness of an industry is the sum of the shortest distance between the industry and all other connected industries. The inverse of farness is closeness. Cannot be calculated as a weighted centrality measure.

Betweenness Is the number of times the industry acts as the shortest path between two other industries. Cannot be calculated as a weighted centrality measure.

Degree Weighted Defined as the number of industries the nodal industry has supplier or customer relationships. Additionally, the number of ties is weighted by the total dollar flow between the two industries.

Eigenvector Each node in the industry network is assigned eigen values. Is the sum of the eigenvalues of the connections of the industry. Additionally, the number of ties is weighted by the total dollar flow between the two industries.

In-degree Is the fraction of the number of industries supplying to the nodal industry.

Out-degree Is the fraction of industries that are customers of the nodal industry.

\section{References}

Aggarwal R, Baxamusa M (2013) Unrelated acquisition. AFA 2013 San Diego Meetings Paper

A'hern KR (2012) Bargaining power and industry dependence in mergers. J Financ Econ 103:530-550

Baxamusa M (2012) The relationship between underinvestment, overinvestment and CEO's compensation. Rev Pac Basin Financ Mark Policies 15(3):1250014-1-1250014-26

Baxamusa M, Georgieva D (2013) Two step acquisitions and the liquidity spread. J Econ Finance 37(4). doi:10.1007/s12197-012-9247-6

Boone A, Mulherin J (2006) Do termination provisions truncate the takeover bidding process? Rev Financ Stud 20(2):461-489

Brass D (1984) Being in the right place: a structural analysis of individual influence in an organization. Admin Sci Quart 29:518-539

Burt R (1980) Models of network structure. Ann Rev Sociol 6(1):79-141

Burt R (2005) Brokerage and closure: an introduction to social capital. Oxford University Press, New York

Erickson M, Wang S, Frank Z (2011) Information uncertainty and acquirer wealth losses. SSRN abstract no. 1031544

Etheridge D (2010) Power and information: the effect of board networks on mergers and acquisitions. Finance and corporate governance conference paper. SSRN abstract no. 1536303

Fan J, Goel V (2006) On the patterns and wealth effects of vertical mergers. J Bus 79:877-902

Freeman L (1979) Centrality in social networks. Conceptual clarifications. Soc Netw 1:215-239

Granovetter M (1973) The strength of weak ties. Am J Sociol 78(6):1360-1380

Grossman S, Hart O (1980) Takeover bids, the free rider problem, and the theory of the corporation. Bell J Econ 11:253-270

Hong H, Scheinkman J, Xiong W (2006) Asset float and speculative bubbles. J Finance 61(3):1073-1117

Jensen M (1986) Agency costs of free cash flow, corporate finance, and takeovers. Am Econ Rev 76:323-329

Khanna N (1997) Optimal bidding for tender offers. J Financ Res 20:323-342

Kohers N, Kohers G, Kohers T (2007) Glamour, value, and the form of takeover. J Econ Bus 59:74-87

Krakhard D, Brass D (1994) Intra-organizational networks: the micro side. Advances in the social and behavioral sciences from social network analysis, pp 209-230

Lang L, Stulz R, Walking R (1989) Managerial performance, Tobin's Q and gains from successful tender offers. J Financ Econ 24:137-154

Lawson T (1997) Economics and realty. London, Routedge

Lee S, Lim K (2006) The impact of M\&A and joint ventures on the value of IT and non-IT firms. Rev Quant Financ Acc 27(2):111-123

Masulis R, Wang C, Xie F (2007) Corporate governance and acquirer returns. J Financ 62(4):1851-1889

Miller E (1977) Risk, uncertainty and divergence of opinion. J Financ 32:1151-1168

Moeller S, Schlingemann F, Stulz R (2004) Firm size and gains from acquisitions. J Financ Econ 73(2):201-228

Myers S, Majluf N (1984) Corporate financing and investment decisions when firms have information that investors do not have. J Financ Econ 13:187-221 
Officer M, Poulsen A, Stegemoller M (2009) Target-firm information asymmetry and acquirer returns. Rev Financ Stud 13(3):467-493

P'astor L, Veronesi P (2006) Was there a Nasdaq bubble in the late 1990s? J Financ Econ 81:61-100

Povel P, Singh R (2006) Takeover contests with asymmetric bidders. Rev Financ Stud 19(4):1399-1431

Roll R (1986) The hubris hypotheses of corporate takeovers. J Bus 59:197-216

Schonlau R, Singh P (2009) Board networks and merger performance, Carnegie Mellon University working paper

Shahrur H (2005) Industry structure and horizontal takeovers: analysis of wealth effects of rivals, suppliers, and corporate customers. J Financ Econ 76:61-98

Travlos N (1987) Corporate takeover bids, methods of payment, and bidding firms' stock returns. J Financ 42:943-963 